IZA DP No. 5747

Surfing Alone? The Internet and Social Capital:

Evidence from an Unforeseeable Technological Mistake

Stefan Bauernschuster

Oliver Falck

Ludger Woessmann

May 2011 


\title{
Surfing Alone? The Internet and Social Capital: Evidence from an Unforeseeable Technological Mistake
}

\author{
Stefan Bauernschuster \\ Ifo Institute, University of Munich and CESifo \\ Oliver Falck \\ Ifo Institute, University of Munich and CESifo \\ Ludger Woessmann \\ University of Munich, Ifo Institute, CESifo and IZA
}

Discussion Paper No. 5747

May 2011

IZA

P.O. Box 7240

53072 Bonn

Germany

Phone: +49-228-3894-0

Fax: +49-228-3894-180

E-mail: iza@iza.org

\begin{abstract}
Any opinions expressed here are those of the author(s) and not those of IZA. Research published in this series may include views on policy, but the institute itself takes no institutional policy positions.

The Institute for the Study of Labor (IZA) in Bonn is a local and virtual international research center and a place of communication between science, politics and business. IZA is an independent nonprofit organization supported by Deutsche Post Foundation. The center is associated with the University of Bonn and offers a stimulating research environment through its international network, workshops and conferences, data service, project support, research visits and doctoral program. IZA engages in (i) original and internationally competitive research in all fields of labor economics, (ii) development of policy concepts, and (iii) dissemination of research results and concepts to the interested public.
\end{abstract}

IZA Discussion Papers often represent preliminary work and are circulated to encourage discussion. Citation of such a paper should account for its provisional character. A revised version may be available directly from the author. 


\section{ABSTRACT \\ Surfing Alone? The Internet and Social Capital: Evidence from an Unforeseeable Technological Mistake*}

Does the Internet undermine social capital or facilitate inter-personal and civic engagement in the real world? Merging unique telecommunication data with geo-coded German individuallevel data, we investigate how broadband Internet affects several dimensions of social capital. One identification strategy uses panel information to estimate value-added models. A second exploits a quasi-experiment in East Germany created by a mistaken technology choice of the state-owned telecommunication provider in the 1990s that still hinders broadband Internet access for many households. We find no evidence that the Internet reduces social capital. For some measures including children's social activities, we even find significant positive effects.

JEL Classification: $\quad$ Z13, J24

Keywords: Internet, social capital

Corresponding author:

Ludger Woessmann

ifo Institute for Economic Research

at the University of Munich

Poschingerstr. 5

81679 Munich

Germany

E-mail: woessmann@ifo.de

\footnotetext{
* Comments by Sascha Becker, Rob Fairlie, Bob Hart, Ofer Malamud, Jonathan Robinson, Jens Suedekum, and seminar participants at UC Santa Cruz, U Stirling, DIW Berlin, U Munich, U DuisburgEssen, and U Passau are gratefully acknowledged. Falck is indebted to the Economics Department, UC Santa Cruz, and in particular to Rob Fairlie, for their hospitality during the research visit that allowed work on this research. We would also like to thank the DIW for the GSOEP data access and in particular Jan Goebel for his permanent support. The research underlying this paper has been partially supported by Deutsche Telekom AG. The views expressed are those of the authors and do not necessarily reflect the views of Deutsche Telekom AG.
} 


\section{Introduction}

In his seminal book, “Bowling Alone,” Robert Putnam (2000) laments the decline of social capital in modern times that threatens to undermine our societies. Part of the blame for this has been placed on the advent of new technologies for information, communication, and entertainment that keep people from civic engagement and from connecting to their communities. The prime example is the television; Olken (2009) confirms empirically that TV consumption crowds out social participation in the context of a developing country. Less obvious is the effect of Internet access on social capital. On the one hand, the Internet obviously absorbs a lot of people's time, which may come at the detriment of social engagement and substitute real-world interaction with solitary entertainment in the virtual world. On the other hand, the Internet may help people to connect in the virtual world. It may in fact also facilitate social interaction in the real world by providing easy access to relevant information and reducing transaction costs to meet other people in such places as theaters, concerts, and bars. As Putnam (2000) put it, “The Internet may be part of the solution to our civic problem, or it may exacerbate it” (p. 170). There is anecdotal evidence that both aspects are at play - nerds disconnecting from their community by spending their life with online games, but also websites to inform oneself about what is going on in town, to learn about possibilities for volunteer engagement, and eventually for dating. However, little is known about which is the dominating force, a question crucial for assessing the societal repercussions of the mass medium of the twenty-first century.

This paper estimates the effect of broadband Internet access on social capital. The rich individual-level data of the German Socio-Economic Panel (GSOEP) provides information on a battery of proxies for several dimensions of social capital in real-world situations that measure social participation by a wide range of activities. The indicators cover the frequency

of going to theaters, exhibitions, concerts, restaurants, and bars; the frequency of visiting friends and the number of friends; and the prevalence of volunteer work in associations and social services and of political engagement and interest. The GSOEP also provides information on broadband Internet access in the household. However, empirical identification is plagued by the obvious possibility that having high-speed Internet access at home may be endogenous to a person's social capital. Outgoing people may be more likely to make use of the information opportunities provided by the Internet, giving rise to a positive bias in standard estimates of the effect of the Internet on social capital. But the Internet may also 
attract intrinsically seclusive people and social nerds, giving rise to a negative bias. The direction of the possible endogeneity bias is thus not clear a priori.

We propose two identification strategies to address such endogeneity concerns. The first identification strategy exploits the panel structure of our database. In value-added models, we control for individuals' values of social capital before the emergence of broadband Internet (in 2001) when estimating the effect of high-speed Internet access in the household (in 2008) on social capital.

The second identification strategy exploits a quasi-experimental setting in East Germany where an unforeseeable technological mistake in the 1990s cut many people off from broadband Internet access for years. After reunification, telephone access lines, in particular of acceptable quality, were missing in many East German regions. Deutsche Bundespost - the former state-owned monopoly provider of postal and voice-telephony services in Germany decided to provide telephony services by rolling out the so-called OPAL (optical access line) technology in 213 telephone access areas serving 11 percent of East German households. In the 1990s, OPAL was the leading high-end technology for voice-telephony and low-speed digital services. However, when the Internet became a mass phenomenon in the early 2000s, DSL (digital subscriber line) became the leading standard for high-speed broadband access. This turned OPAL into an outdated technology, because - in contrast to classical copper wires - OPAL is not compatible with the DSL standard. Huge investments are necessary to provide high-speed Internet in OPAL areas, which has not occurred in many of the areas until today. The fact that choosing the OPAL technology for the telecommunication network turned out to be a severe mistake was unforeseeable at the time of decision, because broadband Internet did not yet exist at the time. Thus, what turns out to be a mistaken technology choice gives rise to variation in access to broadband Internet in East Germany that is exogenous to people's social capital and not driven by their affinity to connect to the Internet.

In order to exploit this variation, we combine the new GSOEP feature of providing exact geographic coordinates of the surveyed households (in an on-site procedure that ensures

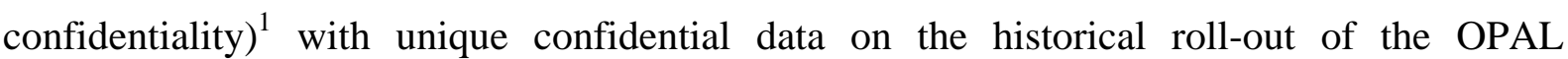
telecommunication technology, kindly provided to us by Deutsche Telekom, the successor for telephony services of Deutsche Bundespost after its privatization in 1995. In our microgeographic data, East German households are assigned to over 1,000 small-scale telephone access areas. This allows us to use the information whether a household is located in a

\footnotetext{
${ }^{1}$ In fact, ours is one of the first academic research projects to make use of the new on-site facility to access information on geo-coordinates of GSOEP households and connect them with external geographic information.
} 
historical OPAL area as an instrument for broadband Internet access at home in 2008, which in fact proves to be a strong instrument.

Our results suggest that the Internet did not undermine social capital. In virtually all specifications and for virtually all social capital indicators, both the value-added models and the instrumental-variable (IV) models yield positive point estimates on having broadband Internet access at home. The precisely estimated value-added models allow rejecting substantial negative Internet effects for all social capital indicators, whereas sizable standard errors preclude such rejections in the IV models. Still, the IV results indicate significant positive effects of broadband Internet access on the frequency of visiting theaters, the opera, and exhibitions and, in the most extensive specification that includes county fixed effects, on the frequency of visiting friends.

Exploring a relatively small sample of children aged 7 to 16 living in the sampled households, we further find evidence that having a broadband Internet subscription at home increases the number of children's out-of-school social activities, such as doing sports or ballet, taking music or painting lessons, or joining a youth club. Broadband Internet access also does not crowd out children's extra-curricular school activities, which include such areas as sports, music, arts, and drama. This finding complements the empirical literature on effects of computers and the Internet on children's cognitive and non-cognitive skills (see Malamud and Pop-Eleches (2011) for an overview).

Several tests of validity and robustness support a causal interpretation of our results. A placebo test corroborates the validity of our instrument: If living in an OPAL area is a source of exogenous variation in broadband Internet access because OPAL is incompatible with the DSL broadband technology, it should predict households' high-speed Internet access after the emergence of the DSL broadband technology, but not (low-speed) Internet access before the emergence of broadband Internet. The panel structure of our dataset allows us to confirm that our instrument, which measures the technological situation in 1998, is indeed not associated with low-speed Internet access in 2000, but does predict broadband Internet access in 2008. Our results are also robust to controlling for pre-broadband-Internet economic development, for several indicators of centrality and access to other infrastructure, and even for county fixed effects. The identified variation in Internet access is thus unlikely to capture other features that might distinguish OPAL areas from non-OPAL areas. Given our detailed microgeographic data, we can also show that results are robust to restricting the control group of households living in non-OPAL areas to those living close enough (3.5 km) to a main distribution frame to be sure that high-speed Internet access is in fact technologically viable. 
The remainder of the paper is organized as follows. Section 2 places our study in the broader literatures on Internet and social capital and provides some conceptual background on how the Internet may affect social capital. Section 3 introduces our data on social capital and Internet access and provides descriptive evidence on the characteristics of broadband Internet users. Section 4 reports the association between home broadband Internet access and social capital. Section 5 exploits the panel structure of the data to estimate value-added models. Section 6 develops our quasi-experimental identification strategy, presents the IV results, and discusses instrument validity and robustness. Section 7 analyzes the effect of home broadband Internet access on social and extra-curricular activities of children. Section 8 concludes.

\section{The Internet and Social Capital: Some Theory and Related Literature}

An emerging literature studies the economic effects of the rise of the Internet (see, e.g., Varian (2010)). Aggregate cross-country evidence suggests that broadband infrastructure has an important impact on economic growth (Czernich, Falck, Kretschmer, and Woessmann (2011)). At a general level, the question arises how a general purpose technology like the Internet affects people's daily lives and decisions (see Helpman (1998)). Residential broadband infrastructure may facilitate the emergence of new work practices (Autor (2001)), home-based entrepreneurship (Fairlie (2006)), and job search (Krueger (2000); Autor (2001); Stevenson (2009)). Our analysis complements these studies by investigating the effects of the Internet on yet another economically relevant outcome, namely social capital.

A large literature addresses the economic consequences of social capital (see Sobel (2002) and Durlauf and Fafchamps (2005) for surveys). Measures of social capital are related to economic performance across countries (see, e.g., Temple and Johnson (1998) and the references therein). Social capital matters for a variety of economic outcomes, in particular in the presence of asymmetric information and incomplete contracts. To name but a few examples that relate directly to individual networks, social capital is found to matter for job search (Mouw (2003); Bayer, Ross, and Topa (2008)), financial development (Guiso, Sapienza, and Zingales (2004)), entrepreneurial finance (Sanders and Nee (1996); McMillan and Woodruff (1999)), and firm location (Michelacci and Silva (2007)). Given the complexities of identification, work on the determinants of social capital is only starting to emerge (see Glaeser, Laibson, and Sacerdote (2002); Durlauf and Fafchamps (2005)).

From a conceptual point of view, social capital may be both negatively and positively affected by the Internet (for general discussions, see Putnam (2000), Chapter 9; Huysman and 
Wulf (2004)). On the one hand, if the Internet is mostly used for passive entertainment, then similar to the television - it may crowd out social participation. ${ }^{2}$ Performing transactions like shopping and banking on the Internet may deprive people from face-to-face interactions (Franzen (2003)). The Internet may also increase the separation of communication into separate groups with specific interests (sometimes referred to as “cyber-balkanization”, see Van Alstyne and Brynjolfsson (1996)), so that even if it lowers individual separation, it can at the same time increase group separation and community fragmentation (Rosenblat and Mobius (2004)). Furthermore, communication through the Internet may miss a lot of the nonverbal information transmitted in face-to-face communication.

On the other hand, there are also possible positive effects of the Internet on social capital. The information function of the Internet means that it facilitates the acquisition of information about places and times of social events, reduces transaction costs of reserving places or buying tickets for certain events, provides information on politics and civic initiatives, and even helps to find out about opportunities for volunteer engagement and proper matches to individuals’ preferred social engagements. For example, many websites in Germany serve to connect people in the local region and enable political blogging. Furthermore, the communication function of the Internet means that it may make social interaction more convenient and efficient (e.g., Pénard and Poussing (2010)) and help interpersonal exchange by desynchronizing communication in time and space. This feature of interactivity distinguishes the Internet from the television.

The empirical knowledge about how the Internet affects social capital is limited so far (see Pénard and Poussing (2010) for a recent review of descriptive studies on the subject). Moreover, the evidence, while informative, is inconclusive (see, e.g., Franzen (2003)) and usually fails to identify correlation from causation (see below).

\section{Individual-Level Data on the Internet and Social Capital}

The German Socio-Economic Panel (GSOEP) is a representative annual household survey covering a wide range of topics pivotal for social science. In 2008, roughly 20,000 adult individuals living in more than 11,000 households participated in the interviews. The GSOEP wave 2008 provides information on whether Internet access is available at all in a household and, for the first time, whether this Internet access is based on a high-speed

\footnotetext{
2 This effect may be of particular interest among adolescents, not least because of the mixed evidence on effects of the use of computers and the Internet on academic achievement (see Malamud and Pop-Eleches (2011) and the literature overview therein).
} 
connection realized via DSL, the standard broadband technology in Germany. Additionally, extensive information is available on individuals' background characteristics such as gender, age, marital status, number of children in the household, secondary and university education, occupational status, migration background, ownership of a house or flat, and net household income. Table 1 presents descriptive statistics on these variables.

In measuring social capital, we aim to capture aspects of social capital in the "real" world. It is obvious that Internet users may have more "virtual" contacts, but our interest is in the effect of Internet access on real-world social engagement. Since social capital is a rather broad concept in the economic literature, we explicitly aim to take account of a wide range of proxies that capture different dimensions of social capital in our analysis. Here, again, the GSOEP provides extensive and valuable information. Putnam (2000) distinguishes two general forms of real-world social engagement: People who spontaneously invest time in informal conversation by such activities as frequenting bars and meeting friends, and people who invest time in formal organizations by such activities as volunteer work and political engagement (which he refers to as "schmoozers" and “machers,” pp. 93-95). Both dimensions of social connectedness are important, and we aim to capture both of them with our set of social capital indicators.

Thus, our first set of social capital measures captures informal dimensions of getting connected in the real world: the frequency of "attending events like opera, classic concerts, theater, exhibitions," of “attending cinema, pop or jazz concerts, dance events/disco,” and of "going out for food or a drink (café, bar, restaurant)." All three measures for social participation draw on categorical information on how individuals spend their leisure time, with five answer options ranging from "never," "less than once a month," "at least once a month,” and "at least once a week" to "every day.” Our second set of social capital measures captures interaction with friends, which may be viewed as combining informal and formal elements of social connectedness: one indicator, measured in the same categorical way, measures the frequency of “mutual visits of neighbors, friends, and acquaintances," and another indicator is the answer to the simple question about the number of close friends. Finally, our third set of social capital measures captures more formal dimensions of social engagement: two categorical variables measuring the frequency of "volunteer activity in clubs, associations, and community services" and of "participation in political parties, in local politics, and civic initiatives," and a third categorical variable referring to how strongly the person reports to be interested in politics (answer options ranging from "not interested at all," 
"not strongly," and “strongly” to “very strongly”). Table 2 reports descriptive statistics on the full battery of measures of social capital, where all measures are coded so that higher values reflect higher levels of social and political engagement.

In 2008, 56 percent of all individuals in the GSOEP had broadband Internet access via DSL at home. This number is significantly higher in West Germany (60 percent) than in East Germany (41 percent). ${ }^{4}$ This lower broadband penetration of East Germany is partly due to the DSL incompatibility of the OPAL technology used in some East German areas which we exploit in our quasi-experimental evidence below.

To get a first impression of the characteristics of the group of broadband Internet users, Table 3 presents linear probability models that regress a dichotomous variable indicating broadband Internet access at home on the set of background characteristics. ${ }^{5}$ The descriptive pattern reveals that women are somewhat less likely to have access to broadband Internet at home than men. The relationship between age and home broadband Internet access has an inverted U-shape. The probability of having broadband Internet access at home is higher for married individuals and increases with the number of children living in the household, the level of secondary schooling, and with university education. Unemployed, retired, and other non-working persons, as well as blue-collar workers, are less likely to have broadband Internet access than apprentices, white-collar workers, and entrepreneurs. Furthermore, the likelihood of having broadband Internet access is higher for natives and for owners of a house or flat and increases with household income.

\section{The Association between the Internet and Social Capital}

We start our empirical investigation whether individuals with broadband Internet access at home participate more or less often in social activities than individuals without home broadband Internet access with a look at the simple cross-sectional association. We regress each of the social capital variables $S_{i}$ on a dummy for home broadband Internet access $I_{i}$ and a vector of covariates $X_{i}$ :

$$
S_{i 2008}=\alpha+\beta I_{i 2008}+X_{i 2008} \gamma+\varepsilon_{i}
$$

${ }^{3}$ Additional possible proxies for social capital with which we have experimented include the frequency of meeting relatives, contacting friends and relatives abroad, active sports exercise, and attending sports events. Results (available from the authors on request) are similar to the patterns reported here.

${ }^{4}$ Similarly, if we substitute the federal state dummies in the multivariate regression of Table 3 by an indicator for East Germany, the coefficient on the East Germany dummy is -0.148 ( $p$-value 0.000).

${ }^{5}$ Probit models yield very similar results. 
Apart from the 22 individual-level covariates presented in Table 3, the control vector $X_{i}$ includes fixed effects for the 16 German federal states. As broadband Internet access is captured at the household level, the standard errors $\varepsilon_{i}$ are clustered at the household level (Moulton (1986)). For comparability, we standardize all social capital measures to a mean of zero and a standard deviation of one throughout.

Table 4 presents the results of linear regressions for each measure of social capital in the sample of roughly 18,000 individuals. Conditional on the covariates, there is a positive association between having broadband Internet access at home and all our social capital measures, statistically significant for six of the eight measures. All three indicators in the first set of social capital measures on informal connections - attending theaters, operas, and exhibitions; cinema and concerts; and restaurants and bars - are significantly positively associated with Internet access. In the second set of friendship-related measures, just the number of close friends captures statistical significance in the OLS model. ${ }^{6}$ In the third set of measures of formal social engagement, the coefficient on broadband Internet access captures significance for volunteer work and for general interest in politics. In terms of magnitude, for example, having broadband Internet access at home is related to a 10.1 percent of a standard deviation higher frequency of attending theater plays, operas, and exhibitions.

Given the categorical nature of the original data of the dependent variables, rather than $z$ standardizing and estimating by linear models, we can also estimate ordered logit models of the original categorical variables. Results, reported in Table A1 in the appendix, are qualitatively the same, with the sole exception that the positive average association of broadband Internet access with volunteer work becomes statistically insignificant. The marginal effects, which depict the effect magnitude category by category, suggest that broadband Internet access reduces the probability of never going to the theater, opera, and exhibitions, for example, by 5.4 percentage points and increases the probabilities of going less than once a month by 3.4 percentage points and of going at least once a month by 1.9 percentage points. By contrast, the highest positive marginal effects are in the "at least once a month" category for cinema and concerts and in the "at least once a week" category for restaurants and bars, where the highest negative marginal effects are in the "never" and "less than once a month" categories, respectively. In terms of interest in politics, the "not at all" and "not strong" categories both lose in favor of the "strong" category. The fact that, across the dependent variables, the marginal effects of Internet access tend to be strongest in the

\footnotetext{
${ }^{6}$ The result on the continuous variable of number of friends is robust to dropping the few outliers with very high values (see Table 2).
} 
lowest two categories without comparably strong effects in the highest category suggests that the Internet is not related to a polarization of social capital measures.

As roughly a quarter of individuals with a personal computer at home do not have broadband Internet access, there is, in general, enough variation to test whether the overall picture is also confirmed when additionally controlling for a personal computer at home. We find that the associations with Internet access are in fact robust in such specifications. ${ }^{7}$ However, conditioning on having a personal computer at home may rule out indirect channels of broadband Internet access on social capital, for example if some individuals refrain from purchasing a personal computer because the value of its use is strongly reduced for them due to a lack of broadband Internet access.

\section{Value-Added Models with Lagged Dependent Variables}

Causal interpretation of the associations reported so far, albeit conditioning on a large set of socio-economic covariates, is obviously hindered by a range of endogeneity concerns. For example, reverse causality might arise if politically interested individuals are more likely to buy broadband Internet access exactly because they are politically interested and would like to use the Internet to get better information on politics. Omitted variables are another source of endogeneity concerns, for example when outgoing and open-minded individuals socialize more and at the same time are more susceptive to new technological developments like broadband Internet. Both types of selection would bias OLS estimates upwards. On the other hand, selection may also take the form that shy, lonely, and solitary individuals subscribe to broadband Internet access because they have less social contacts in the real world and look for compensation in the virtual world. Such selection would bias OLS estimates downwards. Thus, the degree and direction of bias in the reported associations is not clear a priori.

A first way to address the selection concerns is to exploit the panel structure of the GSOEP database to control for pre-existing levels of social capital. Estimates of such valueadded models are not affected by time-invariant unobserved individual traits that relate both to having broadband Internet access at home and to the social capital measures. The year 2001 provides a convenient date to measure the lagged dependent variable, as most of our social capital measures (which are not surveyed every year) were surveyed in 2001 and as

\footnotetext{
${ }^{7}$ Detailed results are available from the authors on request.
} 
broadband Internet was hardly existent in $2001 .^{8}$ Constructing a sample of individuals who responded both in 2001 and in 2008 leads to a sample reduction by about 31 percent of the original sample (see Tables 1 and 2 for descriptive statistics of the reduced sample).

The value-added model expresses current social capital $\left(S_{i 2008}\right)$ as a function of having broadband Internet access in 2008 ( $\left.I_{i 2008}\right)$, the vector of controls in $2008\left(X_{i 2008}\right)$, and the lagged social capital variable in $2001\left(S_{i 2001}\right):^{9}$

$$
S_{i 2008}=\alpha+\beta I_{i 2008}+X_{i 2008} \gamma+\lambda S_{i 2001}+\varepsilon_{i}
$$

The identifying assumption of this specification is that there are no unobserved confounding factors that varied between 2001 and 2008 in a way that is correlated with broadband Internet access. Under this assumption, the coefficient on the broadband Internet indicator reflects the effect of gaining broadband Internet access on social capital. Time-invariant omitted individual traits that affect the level of social capital in both years are accounted for in the value-added specification. The 2001 value of social capital cannot be affected by broadband Internet as it was hardly available then.

Table 5 shows the results of the value-added models. ${ }^{10}$ Also after conditioning on the corresponding lagged social capital variable measured in 2001, broadband Internet access in 2008 is positively associated with all social capital variables in 2008. That is, even controlling for time-invariant heterogeneity, there is not a single negative point estimate on broadband Internet access. Nearly all point estimates are reduced in size, however, and they capture statistical significance only in the three value-added models of our first set of mostly informal social capital measures - attending theater, opera, and exhibitions; cinema and concert; and

\footnotetext{
${ }^{8}$ The number of friends was not asked in the 2001 wave of the GSOEP but only in 2003 when broadband Internet was already available in Germany. Estimating a value-added model with the 2003 data yields a positive yet insignificant effect of broadband Internet on the number of friends. Most of the other social capital variables were asked in 2001 in the same way as in 2008. Slight exceptions are that the question on "attending events like opera, classic concerts, theater, exhibitions" was phrased "attending cultural events, e.g., concerts, theater, lectures" in 2001 and that the question on "attending cinema, pop or jazz concerts, dance events/disco" was phrased "attending cinema, pop concerts, dance events, discos, sports events" in 2001. As the lagged social capital control for the 2008 categories of "going out for food or a drink (café, bar, restaurant)" and "mutual visits of neighbors, friends, and acquaintances," we use the 2001 category of "sociability with friends, relatives, or neighbors."

${ }^{9}$ Note that in a value-added model with current and past controls where the impact of past controls is modeled to diminish with increasing time lags according to a geometric series $\left(\beta \lambda^{\text {lag }}\right.$, where $\left.0<\lambda<1\right)$, all past controls drop out and are implicitly captured by the lagged social capital variable when taking first differences (the social capital equation in 2008 minus $\lambda$ times the social capital equation in 2001).

${ }^{10}$ Results for all control variables in these and the subsequent specifications are available from the authors upon request.
} 
restaurant and bar. Thus, the significant effects all relate to social events where the Internet, in addition to its information function, might facilitate reserving and purchasing tickets.

The coefficients on the lagged social capital variables are statistically highly significant in all models and contribute to their explanatory power. The size of the coefficients suggests that persistence over time is particularly strong in the third set of measures of more formal civic engagement - volunteer work, political engagement, and interest in politics. By contrast, the predictive power of going to restaurants and bars in the past for today's socializing in restaurants and bars is less strong. Also in the areas of going to the cinema and concerts and of visiting friends, individual activity seems to have changed more over time.

The value-added models address endogeneity problems arising from unobserved timeinvariant individual traits that are related both to the social capital variables and to having broadband Internet access. However, the value-added estimates would still be biased if there were unobserved individual traits that changed between 2001 and 2008 in a way related to both social capital and the probability of subscribing to broadband Internet at the same time. Therefore, in the next section, we explicitly model a source of exogenous variation in broadband Internet access.

\section{Quasi-Experimental Evidence: An Unforeseeable Technological Mistake}

\subsection{The OPAL Technology in East Germany}

After German reunification in 1990, there was a huge lack of telephone access lines in many parts of East Germany. Indeed, the German Democratic Republic (GDR) was often labeled a developing country in terms of telephone infrastructure. To overcome the legacy of the communist regime, Deutsche Bundespost $(\mathrm{DBP})^{11}$ decided to roll out telephony infrastructure built on the basis of a special type of fiber wires, the so-called OPAL technology, instead of the traditionally used copper wires. In the early 1990s, this technology was regarded the state-of-the-art technology that would dominate the ICT future. It is suited for voice-telephony services, ISDN (integrated services digital network) services, and for a limited amount of data transmission (Ranft (1997)). Relying on this progressive technology, DBP expected to be prepared for the demand of the next decades. OPAL technology was eventually rolled out in 213 East German areas covering about 11 percent of East German households. Even the press was enthusiastic about DBP's high-tech project and nominated

\footnotetext{
${ }^{11}$ In the early 1990s, voice telephone services were solely provided by the state-monopolist Deutsche Bundespost, the integrated carrier for postal and telephony services.
} 
DBP's Chief Technology Officer as the "Fiber Man of the Year." As an example from the German press, VDI Nachrichten wrote (6 December 1991, own translation): "Former GDR becomes model country of fiber technology. In the former developing country of telecommunication, DBP Telekom wants to build the most modern fiber network worldwide and carry it all the way to the customer. [...] Thereby, the new federal states will receive the most modern telecommunication network in the world.”

But subsequently, things changed dramatically: The telecommunication markets were liberalized across Europe; DBP was split into two privately operated firms, Deutsche Post for postal services and Deutsche Telekom for telephone services. Most importantly, the world saw the Internet revolution taking over. The Internet became a mass phenomenon and services on the Internet demanded higher and higher bandwidth. Finally, to meet this demand, DSL technologies became the leading standard of access technologies for broadband Internet. DSL technologies are highly attractive because they rely on the copper wires of the pre-existent voice-telephony network, which makes the supply of broadband Internet via DSL relatively cheap.

This development was beneficial for most parts of Germany. However, it was a misfortune for the thought-to-be-high-tech OPAL areas. Nobody could have guessed that the appraised OPAL technology would, only a few years later, turn out to be a major disadvantage for regional development. The reason for this is that OPAL technology is simply not compatible with DSL technologies. Thus, by this unforeseeable technological accident, OPAL areas were cut off from high-speed Internet. In order to still provide broadband Internet to OPAL areas, Deutsche Telekom was confronted with two very costly alternatives: They could either replace the OPAL wires of the access network by copper wires, which requires expensive excavation works, or - even more expensively - install new hardware and software at the network's nodes. Thus, by the early 2000s, the sentiment in the German press had changed all over, castigating DBP's decision to roll out OPAL technology in East Germany as a money pit; for example, the leading business weekly Wirtschaftswoche titled (13 September 2001, own translation), “Deutsche Telekom: Burial of billions.”

This unforeseeable technological mistake provides us with exogenous variation in the access to broadband Internet across households. We view this technologically determined variation as randomly allocated (we come back to testing this below) and exploit it as a quasiexperiment in an instrumental-variable (IV) approach. A nice description of why this mistaken technological decision could happen is provided by online magazine Telepolis (12 February 2001, own translation): "Why did no one, in the conceptual design of OPAL, think 
of the potential problems with DSL? Because the Telekom [...] had anticipated in 1990 the Internet Revolution as little as Honecker [the long-term leader of the GDR] in 1985 the fall of the wall.” In fact, given that OPAL was the most modern technology at the time, if anything its roll-out might have been related to favorable rather than dismal conditions; the fact that it later turned out to be a hindrance for broadband Internet access might thus work against finding positive effects of the Internet. However, our robustness analyses below support the interpretation that the OPAL roll-out was statistically exogenous to the variables of interest in our model.

Since 2003, Deutsche Telekom has invested millions of Euros to replace OPAL technology in about half of the original OPAL areas. Nevertheless, as of August 2009, OPAL technology was still in use in 103 areas. Because decisions to subsequently replace OPAL are likely endogenous to the variables of interest in our model, we use the initial roll-out of OPAL as of 1998 (by which time OPAL roll-out had been completed), rather than actual OPAL incidence in 2008, as our instrument for access to broadband Internet at home.

In the remaining OPAL areas, East German households still have limited access to broadband Internet because, in contrast to the United States, the availability of other access technologies is restricted in Germany, and often more expensive than broadband Internet access via DSL. In 2009, Germany had 25.0 million broadband subscribers. Of these, 22.4 million subscriptions were realized via DSL and only 2.6 million via other access technologies (such as TV cable, power line, or satellite; see Bundesnetzagentur (2010)). As an average of the East German counties in 2005, only 6.9 percent of the population could theoretically access broadband Internet via TV cable (own calculations based on the data underlying the Broadband Atlas (Bundesministerium für Wirtschaft und Technologie (2011)). Moreover, in county-level regressions, we confirm that the availability of broadband Internet via cable TV is not correlated with the number of OPAL areas in a county (whereas, in line with the basic idea of our identification, the availability of broadband Internet via DSL is negatively associated with the number of OPAL areas in the same county-level regressions). ${ }^{12}$

Thus, individuals in the remaining OPAL areas who want to access the Internet are only left with the choice of dial-up type technologies such as modems and ISDN, which provide access at very low speed only. Even in the best case of high-end ISDN access, the maximum

12 Detailed results are available from the authors on request. Broadband access through power line or satellite has so far been virtually non-existent in Germany, and third-generation mobile technology - whose speed is still far below standard broadband access and whose private use has been barred by expensive prices over most of our observation period - was not yet available in the majority of East German communities in 2008 (Bundesministerium für Wirtschaft und Technologie (2011)). 
available speed is $128 \mathrm{kbit} / \mathrm{s}$, compared to a broadband DSL standard of $6 \mathrm{Mbit} / \mathrm{s}$. That is, a standard website of $1 \mathrm{MB}$ (which is less than the entry site of standard German newspapers or of Ticketmaster), for example, which takes 1.3 seconds to download with standard DSL, would take more than a minute at the very least to download with the low-speed alternatives (an underestimate of the real problem in times when most websites require computer responses). This makes effective use of most Internet facilities today impossible.

\subsection{Instrumental-Variable Model and Results}

Our IV approach uses information whether a household is located in a telephone access area $a$ that (as of 1998) used the OPAL technology $\left(O P A L_{a}\right)$ as an instrument for whether an individual $i$ (living in telephone access area $a$ in county $c$ ) has home broadband Internet access via DSL $\left(I_{i a c}\right)$ in 2008. Thus, our two-stage model can be described by the following two equations:

$$
\begin{gathered}
S_{i a c 2008}=\alpha+\beta I_{i a c 2008}+X_{i a c 2008} \gamma+C_{c 1995} \delta+\lambda S_{i a c 2001}+\varepsilon_{i a c} \\
I_{i a c 2008}=\eta+\chi O P A L_{a 1998}+X_{i a c 2008} \theta+C_{c 1995} \xi+\phi S_{i a c 2001}+\mu_{i a c}
\end{gathered}
$$

As the OPAL technology was rolled out at a large scale only in East Germany, we restrict our sample in the IV models to East German households (without Berlin), which reduces the sample size by more than three quarters to about 2,800 individuals. ${ }^{13}$ As our instrument provides variation at the level of telephone access areas, standard errors in the IV models are clustered at this level.

The identifying assumption of the IV model is that a household's location in a telephone access area originally covered by the OPAL technology is unrelated to social capital except for the possible indirect effect through broadband Internet access. Possible threats to this identification would arise if, for example, OPAL technology had been primarily used in agglomerated, economically prosperous regions. Therefore, in addition to the vector of individual-level covariates $X_{\text {iac2008 }}$ and the lagged social capital variable $S_{\text {iac2001, }}{ }^{14}$ in the IV models we include two county-level controls $C_{c}$ - GDP per capita and population density (provided by the Statistical Offices of the German Federal States) - measured in 1995, at the

\footnotetext{
${ }^{13}$ As is evident from Table A2 in the appendix, the pattern of results of the basic added-value models on the East German sample is quite similar to the full-sample results of Table 5, albeit at lower levels of statistical precision due to the substantially smaller sample size.

${ }^{14}$ We directly combine the IV identification with the value-added specification, as IV specifications that do not control for lagged values of the dependent variable (available on request) yield very similar results.
} 
time OPAL was rolled out. Further tests of the validity of the identifying assumption are provided below.

To implement our IV approach, we draw on two unique data features. Within a telephone access area, all households are connected to the higher level of the telecommunication network (the "backbone") via the same main distribution frame (MDF) (see Figure A2 in the appendix for a stylized picture of the structure of a broadband network). Thus, first, Deutsche Telekom kindly provided us with their confidential data on the exact geographic extensions of the area-code areas as well as on which MDFs had at some time used the OPAL technology, which we geo-coded for use in our analysis. Second, we merge these data with the GSOEP individual-level data by using exact geo-coordinates of the GSOEP households, a newly established feature of the GSOEP (only available for in situ work). This allows us to generate micro-regional information at the household level on whether the household is connected to an MDF that (historically) uses the OPAL technology or not.

Figure 1 provides an impression of the small-scale geographic structure of our data. It shows the distribution of the distance of individuals to the MDF to which their household is connected. ${ }^{15}$ The average distance of a household to its MDF is less than 2 kilometers (1.2 miles); the median distance is as low as 1,379 meters. When splitting up the sample into individuals living in OPAL areas and living in non-OPAL areas, the picture is very similar for both groups (see Figure A1 in the appendix). The distance to the MDF in non-OPAL areas is not significantly different from the respective distance in OPAL areas. In non-OPAL areas, households located not too far from the MDF can access high-speed internet. ${ }^{16}$ By contrast, in OPAL areas the OPAL technology hinders the supply of Internet at high-speed bandwidth as long as the fiber wires of the access network are not replaced by copper wires.

Table 6 shows the results of our IV models for the different social capital variables. The first stage indicates that the instrument is indeed a relevant predictor of broadband Internet access at home. ${ }^{17}$ In OPAL areas, the likelihood of having home broadband Internet access is

\footnotetext{
${ }^{15}$ Most area-code areas, for which we have the exact geographic extensions, have only one MDF, so that we can exactly determine the MDF to which a GSOEP household is connected. For the limited number of larger cities that have more than one MDF within one area-code area, we match each GSOEP household to that MDF that is closest to the household within the area-code area.

${ }^{16}$ In non-OPAL areas, the bandwidth that a household can subscribe to is a function of its distance to the MDF. A distance of less than $2 \mathrm{~km}$ on average suggests that households in these areas can at least subscribe to DSL at a bandwidth of $6 \mathrm{Mbit} / \mathrm{s}$; see below for additional analysis.

17 The shown first stage relates to the model with "Theater, opera, and exhibitions" as the dependent variable. Due to slight variations in the number of missing values and to the different lagged outcome variable that is included in the models, the first-stage models differ slightly for the other outcome variables, but only in the third digit (between 0.110 and 0.115 ; detailed results available on request). Respective F-statistics of the instrument in the first stage of all models are reported at the bottom of Table 6 .
} 
11 percentage points lower than in non-OPAL areas. The $F$-statistic of the excluded instrument, ranging from 16.5 to 18.1 for the different outcome variables, suggests that living in a (historical) OPAL area is a relevant instrument for individual home broadband Internet access in 2008. Neither GDP per capita nor population density, measured at the county level in 1995, enter the first-stage model significantly, reducing concerns that features of the initial OPAL roll-out interfere with our identification.

The second-stage results of the IV models are in line with the value-added models: There is not a single negative coefficient of home broadband Internet access on the different social capital measures. At the same time, however, the effect of home broadband Internet access is significantly different from zero only for attending theater, opera, and exhibitions. The lack of significance for the remaining outcome variables is due to the relatively large standard errors of the estimated coefficients. Tests for exogeneity, based on robust regressions, provide no sign of endogeneity for all insignificant IV coefficients of home broadband Internet access relative to the coefficients estimated in the standard value-added models for the East German subsample (see Table A2 in the appendix), suggesting that we might trust the more efficient value-added models. We do not find systematic heterogeneity in the second-stage coefficients of home broadband Internet access across different subgroups of individuals (not shown).

The significant estimate for theater, opera, and exhibitions, as well as several of the insignificant point estimates, are substantially larger than in the OLS and value-added models. We see three possible explanations that may all contribute to this pattern. First, among the possible biases in the OLS estimates discussed above, the downward biases may dominate the upward biases: People who tend to scare away from real-world social contact disproportionately select into having broadband Internet access, presumably because it offers them a good opportunity to avoid real-world social interactions. If choosing to subscribe to broadband Internet reflects an increasing trend in the tendency to be intrinsically disconnected from the community, such bias may also affect the value-added estimates reported in the previous section. Second, the non-IV estimates may suffer from attenuation bias due to measurement error. Apart from standard response errors, respondents may not be fully aware of the broadband status of their Internet connection. Instrumenting by an independent source of information about the availability of broadband access, namely the OPAL technology of the telecommunication network, solves this attenuation bias.

Third, the causal effect of broadband Internet access on social capital may possibly differ between the total population and the subgroup of those who change their broadband access status because of its unavailability due to the OPAL technology. In a local average treatment 
effect (LATE) interpretation, treatment effects may not be homogenous in the population. The IV approach identifies the treatment effect for the subpopulation of compliers who change their treatment status due to the variation induced by the instrument. In our case, the complier subpopulation comprises those individuals who do not have access to broadband Internet at home for the exogenous reason of living in a (historical) OPAL area, but would otherwise have subscribed to broadband Internet.

The relative importance of these three explanations is hard to pin down, but it is possible to characterize the subpopulation of compliers (see Angrist and Pischke (2009)). An analysis of the first-stage coefficients by subpopulations suggests a relatively homogenous characterization of compliers relative to the total population in terms of observables, with the exceptions that persons older than 50 years and persons with the lowest educational levels are less likely to comply with the "OPAL treatment.” In addition, there is a stronger effect of OPAL for households with children, a fact that we will address in more detail below. From the first stage, one can also compute the size of the complier subpopulation. The proportion of the treated who are compliers is given by the first-stage coefficient of our instrument, times the proportion of individuals living in OPAL areas, divided by the proportion of individuals who do not have home broadband Internet access:

$$
P\left[I_{1 i a c}<I_{0 i a c} \mid I_{i a c}=0\right]=\frac{\left(\mid E\left[I_{i a c} \mid O P A L_{a c}=1, X_{i a c}\right]-E\left[I_{i a c} \mid O P A L_{a c}=0, X_{i a c}\right]\right) P\left[O P A L_{a c}=1\right]}{P\left[I_{i a c}=0\right]}
$$

Our first-stage result suggests that 3.0 percent of those individuals without access to broadband Internet at home do not have broadband Internet access due to the fact that they live in a (former) OPAL area. This suggests that there is scope for the complier subpopulation identified by our strategy to be relatively special.

\subsection{Instrument Validity and Robustness Tests}

To test the validity of our instrument and the identifying assumption underlying our IV model, we perform a number of specification tests. First, living in an OPAL access area is a valid instrument for home broadband Internet access only if OPAL roll-out does not correlate with pre-existing dispositions in favor of Internet access. It is possible to test this in a placebo test: If the negative first-stage correlation of the OPAL area dummy with high-speed Internet access is indeed due to the technological shortcomings of the OPAL technology, we should find no effect of our instrument on Internet access in years where broadband Internet via DSL 
was not available. In order to test this presumption, we use data on Internet access in a household from the year 2000 wave of the GSOEP. OPAL roll-out had been terminated by 2000. At the same time, 2000 was the very first year in which broadband Internet connections were realized in Germany, and most GSOEP interviews take place in spring. The total number of (the then expensive) broadband subscriptions in 2000 was a mere 0.16 million (Dialog Consult/VATM (2007)), compared to 25 million in 2009. Thus, in 2000 individuals with home Internet access almost exclusively relied on modem or ISDN, that is, low-speed Internet technologies. Consequently, running our first-stage regression on the 2000 data can be interpreted as a placebo treatment test.

As is evident in Table 7, the results of the placebo first-stage regression indeed confirm the interpretation of our instrument: The OPAL area dummy - measured in 1998 - is close to zero, even with a positive point estimate, and far from any conventional significance levels ( $p$-value 0.462) in predicting Internet access in 2000. By contrast, as the second column shows, the OPAL area dummy proves a strong negative predictor for broadband Internet access in 2008 in the same sample ${ }^{18}$ of individuals who were surveyed in both 2000 and 2008 and who did not move from one telephone access area to another in-between, with an estimate comparable to the estimate obtained in the full sample in Table 6.

This finding is encouraging also from another perspective. In 2000, low-speed Internet access at home was still a high-end technological attainment. Note that one source of endogeneity concern was that outgoing and open-minded individuals socialize more and at the same time could be more susceptive to new technological developments and thus be early adopters of a new technology. However, our placebo first-stage result suggests that being an early adopter is not systematically correlated with living in an OPAL area.

A second test of identifying assumptions underlying our IV model addresses its basic exclusion restriction. The IV approach assumes that OPAL area location is not associated with individuals' social capital in any other way than through the indirect channel of broadband Internet access. This exclusion restriction would fail if OPAL areas are different from other telephone access areas in terms of unobserved characteristics that are correlated with social capital. Several potential threats to identification are already excluded by controlling for GDP per capita and population density in 1995. The fact that households in OPAL and non-OPAL areas do not differ in their average distance to the closest MDF (see Figure A1 in the appendix) also excludes fundamental differences in geographical

\footnotetext{
18 The slight difference in the number of observations between the two columns is due to differences in missing values in the control variables in the two years.
} 
remoteness. Yet, being an OPAL area might still proxy for other infrastructure variables. For example, some areas in East Germany that experienced particular political support after German reunification might have received the latest telecommunication technology and, simultaneously, benefited from other infrastructure programs. We test whether OPAL areas benefited from other infrastructure programs using county-level infrastructure data from the Federal Office for Building and Regional Planning (Maretzke (2005)). These measures capture, in terms of travel time, how easily the three nearest agglomerations can be accessed by car or train, how easily European metropolises can be accessed by car and airplane, and how easily the county can be reached with modern transportation systems. The results in Table 8 show that including these county-level infrastructure indicators in our IV models does not change the basic results.

Third, in order to restrict the analysis to only small-scale geographic variation, the specifications in Table 9 include a full set of county fixed effects. In total, the East German sample covers 1,036 telephone access areas located in 111 counties. Here, identification comes from within-county variation, comparing individuals living in different telephone access areas within the same county. These areas of course differ in terms of telephone infrastructure (OPAL vs. non-OPAL) but, due to their geographic proximity, are plausibly similar to each other in terms of other factors such as traffic infrastructure, amenities, and the local labor market. Again, our pattern of results is robust in this specification: There are no significant negative effects of broadband Internet access on the social capital measures. While there are negative point estimates for some of the social capital measures, they are all very small and close to zero. By contrast, in addition to the significant positive effect on attending theater, opera, and exhibitions, the positive coefficient on visiting friends also becomes statistically significant in the demanding specification with county fixed effects.

Fourth, some households in the control group located in non-OPAL areas may in fact not have effective access to broadband-speed Internet because with the DSL technology, the possible bandwidth of Internet access is a declining function of the distance between the household and its MDF. Thus, to restrict the control group of households located in nonOPAL areas to those who technically have access to broadband Internet, in another robustness specification we drop those individuals in the non-OPAL part of the sample who live in households located more than $3.5 \mathrm{~km}$ away from the closest MDF. For these individuals, DSL is typically only available at a bandwidth of about $1 \mathrm{Mbit} / \mathrm{s}$. Thus, similarly to individuals living in OPAL areas, these individuals are cut off from high-speed Internet access. Again, 
the results in this subsample do not differ systematically from the results for the full sample (see Table A3 in the appendix). ${ }^{19}$

Finally, the fact that at least for attending cultural events, and possibly for visiting friends, our results indicate significant positive effects of broadband Internet suggests that the information and communication functions of the Internet tend to dominate its entertainment function on average. Suggestive evidence that the Internet is indeed predominantly used for informative and communicative activities comes from a media analysis survey conducted by Arbeitsgemeinschaft Media-Analyse in 2007. The questionnaire surveyed a number of nonexclusive Internet usages among a sample of 18,954 Internet users in Germany. The highest two categories, reported by 94.6 percent and 89.4 percent of respondents, respectively, were use of the Internet for "information search" and for "e-mail." Categories like "news," “services,” and “ordering of products” follow at 71.7, 54.9, and 55.3 percent, respectively. By contrast, only 48.8 percent of respondents report to use the Internet for "entertainment choices.” This is suggestive evidence that the information channel may indeed be a dominating mechanism of the Internet's impact on social capital.

\section{The Internet and Social Activities of Children}

A question of particular interest is how the Internet affects the social engagement of children rather than adults. A growing literature analyzes the effects of computers and the Internet on children's educational achievement, usually with mixed results at best (e.g., Malamud and Pop-Eleches (2011); Vigdor and Ladd (2010)). In terms of effects on social capital, the same negative entertainment function and positive information and communication functions of the Internet hypothesized for adults above may also apply to children and adolescents. However, many observers emphasize possible negative effects of the Internet on the development of non-cognitive social skills among children.

The GSOEP provides information on out-of-school social activities and on extracurricular school activities of children living in the surveyed households. The questionnaire on children's activities is answered by one parent. In 2008, our geo-coded GSOEP data include information on 338 East German children between the age of 7 and 16 (who also have the relevant data on control variables). The mean age is 11.3 in the sample.

\footnotetext{
${ }^{19}$ In another robustness check, we restricted the analysis to a subsample of individuals living in counties that have at least one (former) OPAL area; qualitative results (available on request) do not change.
} 
Among the six possible answer categories of social activities outside school and among the five possible extra-curricular activities in school, parents can tick as many as applicable. The out-of-school activities are "sports, dancing, gymnastics, ballet;" "music or singing lessons;” "art/painting;” “youth fire department, Red Cross, or similar aid organizations;” "youth groups, e.g. scouts/falcons;” and "regular visit of youth centers/houses.” The extracurricular activities are "sports," “music," “arts," “theater,” and “other” group activities in school. From the responses, we calculate simple count measures of the number of out-ofschool social activities and of the number of extra-curricular school activities. With few exceptions, children attend a maximum of two activities each outside and inside school, with on average 0.76 (std. dev. 0.69) and 0.74 (std. dev. 0.83) activities, respectively. Only 15 percent of children are reported to have no out-of school or extra-curricular activity at all.

We use our IV specification to estimate the effect of broadband Internet access at home on the number of social activities of the children. Given the age of the children, we cannot estimate a value-added model with lagged activities before the introduction of broadband Internet as control variable. However, in addition to a child's gender and age, the models control for a large set of family background variables including mother's marital status, schooling and university education, occupational status, and migration background, as well as the number of children living in the household, net household income, and whether the house or flat is rented or owned. At the regional level, the models control for federal state fixed effects as well as county-level GDP per capita and population density in 1995.

Table 10 presents the OLS and IV results for the effect of home broadband Internet access on children. Conditional on the child, mother, and county covariates, OLS regressions show a significant positive association of broadband Internet access at home with the number of children's social activities outside school and an insignificant positive association with the number of children's extra-curricular activities at school.

The first stage of the IV models reveals that for the households with children aged 7 to 16, the OPAL coefficient is larger than for the sample of all East German households. This might indicate that children push parents to subscribe to broadband Internet - an argument put forward by Fairlie (2006) - and that a broadband Internet access at home is not realized only if it is technically not available, as is the case in OPAL areas.

The second-stage IV results show that children and teenagers in households with broadband Internet access on average pursue one out-of-school social activity and 0.5 extracurricular school activities more than children in households without access to broadband Internet, with only the former effect capturing statistical significance. The test for exogeneity 
suggests that the positive association between broadband Internet access and out-of-school social activities in the OLS model is even downward biased relative to the true causal effect. Again, there is no indication of a negative effect on average of the Internet preventing children from participating in real-world group activities. The information and communication functions of the Internet seem to dominate the passive entertainment function: Parents may use the Internet to gather information on clubs, sports, and youth groups suitable for their children, and children may get better connected to their friends via Internet services such as Facebook. In both cases, the Internet furthers children’s social real-world activities.

\section{Conclusions}

How does society change through the introduction of the new technologies for information, communication, and entertainment that arrived over the past decade? Does the advent of modern Internet media overthrow the fundamentals of society? Does a withdrawal into a virtual world alienate humans from one another? This paper examines the effect of broadband Internet access at home on social capital. Based on German individual-level data, we measure social capital in terms of a wide range of measures of social participation in the real world which cover both informal and formal dimensions of social engagement. The measures include such informal interactions as going to theaters and operas, cinema and concerts, bars and restaurants, direct measures of interactions with friends, and more formal civic engagement in volunteer and political work.

We devise two identification strategies designed to address concerns of endogeneity bias in OLS estimates. First, we make use of the panel structure of our data to control for individual levels of social capital that existed before the emergence of broadband Internet. Second, we merge the individual data with unique historical telecommunication data and exact geo-coding of households and telecommunication distribution frames to exploit a quasiexperimental setting that provides us with exogenous variation in broadband Internet availability in East Germany: In the aftermath of reunification, the telecommunication infrastructure in some East German areas was modernized with the OPAL fiber technology, the most up-to-date technology at the time, which later turned out to be incompatible with the DSL standard required for high-speed Internet access when the latter emerged.

Our pattern of results across the two identification strategies provides no indication that the Internet has a significant negative impact on average on any of our social capital measures. Rather, virtually all estimates in both models and for all social capital measures 
point in the positive direction. Further, the value-added models indicate significant positive effects on three measures of informal social interaction - visiting such places as theaters, concerts, and bars - and the more demanding IV models with county fixed effects suggest significant positive effects on attending theater, opera, and exhibitions as well as on visiting friends. Also for children and adolescents, we find no evidence that broadband Internet access crowds out social activities in or out of school, but rather indications that it may support the creation and attendance of social group activities outside school.

Our findings are in clear contrast to the significant negative impact of TV consumption on social capital shown by Olken (2009). It seems that on average, because of the distinguishing feature of interactivity, the Internet is qualitatively different from the television in that its main function is not so much one of passive entertainment. At least in some areas of social engagement, the main function of the Internet seems rather one of active information and communication - which the Internet provides in an individualized form at any time - that is conducive to social interaction. Such an interpretation is in line with the fact that the significant positive effects are found in particular for activities where reserving and purchasing tickets might be easier via the Internet, as well as with suggestive evidence that most people use the Internet for information search and communication, whereas much fewer people use it for mere entertainment purposes.

Of course, our analysis does not capture all relevant aspects of social capital, and our measures of social capital are only indirect. We observe activities where real interactions between individuals can possibly take place, and, eventually, trust between individuals can emerge. This caveat is shared with a vast literature on social capital. But our study does show that broadband Internet does not necessarily crowd out other real-world activities of adults and of children. 


\section{References}

Anell, Patrick, Stephan Jay, and Thomas Plueckebaum. 2007. "Nachfrage nach Internetdiensten: Dienstearten, Verkehrseigenschaften und Quality of Service." wik Diskussionsbeitrag 302. Bad Honnef: wik Wissenschaftliches Institut für Infrastruktur und Kommunikationsdienste.

Angrist, Joshua D., and Jörn-Steffen Pischke. 2009. Mostly harmless econometrics: An empiricist's companion. Princeton, NJ: Princeton University Press.

Autor, David H. 2001. "Wiring the labor market." Journal of Economic Perspectives 15, no. 1: $25-40$.

Bayer, Patrick, Stephen Ross, and Giorgio Topa. 2008. "Place of work and place of residence: Informal hiring networks and labor market outcomes." Journal of Political Economy 116, no. 6: 1150-1196.

Bundesministerium für Wirtschaft und Technologie. 2011. Breitbandatlas. Berlin: BMWi, www.zukunft-breitband.de.

Bundesnetzagentur. 2010. Jahresbericht 2009. Bonn: Bundesnetzagentur für Elektrizität, Gas, Telekommunikation, Post und Eisenbahn.

Czernich, Nina, Oliver Falck, Tobias Kretschmer, and Ludger Woessmann. 2011. "Broadband infrastructure and economic growth." Economic Journal 121, no. 552: 505-532.

Dialog Consult/VATM. 2007. Der deutsche Telekommunikationsmarkt: Zehn Jahre Liberalisierung im Festnetzmarkt. Köln: Verband der Anbieter von Telekommunikations- und Mehrwertdiensten (VATM).

Durlauf, Steven N., and Marcel Fafchamps. 2005. "Social capital." In Handbook of economic growth, edited by Philippe Aghion and Steven N. Durlauf. Amsterdam: North Holland: 1639-1699.

Fairlie, Robert W. 2006. "The personal computer and entrepreneurship." Management Science 52, no. 2: 187-203.

Franzen, Axel. 2003. "Social capital and the Internet: Evidence from Swiss panel data." Kyklos 56, no. 3: 341-360.

Glaeser, Edward L., David Laibson, and Bruce Sacerdote. 2002. "An economic approach to social capital." Economic Journal 112, no. 483: F437-F458.

Guiso, Luigi, Paola Sapienza, and Luigi Zingales. 2004. "The role of social capital in financial development." American Economic Review 94, no. 3: 526-556.

Helpman, Elhanan, ed. 1998. General purpose technologies and economic growth. Cambridge, MA: MIT Press.

Huysman, Marleen, and Volker Wulf, eds. 2004. Social capital and information technology. Cambridge, MA: MIT Press.

Krueger, Alan B. 2000. The Internet is lowering the cost of advertising and searching for jobs. New York Times, July 20, C2. 
Malamud, Ofer, and Cristian Pop-Eleches. 2011. "Home computer use and the development of human capital." Quarterly Journal of Economics 126, no. 2: in press.

Maretzke, Steffen. 2005. "Aktualisierung des Infrastrukturindikators für die Neuabgrenzung der Fördergebiete der Gemeinschaftsaufgabe 'Verbesserung der regionalen Wirtschaftsstruktur'." Bonn: Bundesamt für Bauwesen und Raumordnung.

McMillan, John, and Christopher Woodruff. 1999. "Interfirm relationships and informal credit in Vietnam." Quarterly Journal of Economics 114, no. 4: 1285-1320.

Michelacci, Claudio, and Olmo Silva. 2007. "Why so many local entrepreneurs?" Review of Economics and Statistics 89, no. 4: 615-633.

Moulton, Brent R. 1986. "Random group effects and the precision of regression estimates." Journal of Econometrics 32, no. 3: 385-397.

Mouw, Ted. 2003. "Social capital and finding a job: Do contacts matter?" American Sociological Review 68, no. 6: 868-898.

Olken, Benjamin A. 2009. "Do TV and radio destroy social capital? Evidence from Indonesian villages." American Economic Journal: Applied Economics 1, no. 4: 1-33.

Pénard, Thierry, and Nicolas Poussing. 2010. "Internet use and social capital: The strength of virtual ties." Journal of Economic Issues 44, no. 3: 569-595.

Putnam, Robert. 2000. Bowling alone: The collapse and revival of American community. New York, NY: Simon and Schuster.

Ranft, Reinhard. 1997. "Optische Zugangsnetze der Deutschen Telekom." Deutsche Telekom Unterrichtsblätter 50, no. 4: 212-223.

Rosenblat, Tanya S., and Markus M. Mobius. 2004. "Getting closer or drifting apart?" Quarterly Journal of Economics 119, no. 3: 971-1009.

Sanders, Jimy M., and Victor Nee. 1996. "Immigrant self-employment: The family as social capital and the value of human capital." American Sociological Review 61, no. 2: 231249.

Sobel, Joel. 2002. "Can we trust social capital?" Journal of Economic Literature 40, no. 1: 139-154.

Stevenson, Betsey. 2009. "The Internet and job search." In Labor market intermediation, edited by David H. Autor. Chicago, IL: University of Chicago Press.

Temple, Jonathan, and Paul A. Johnson. 1998. "Social capability and economic growth." Quarterly Journal of Economics 113, no. 3: 965-990.

Van Alstyne, Marshall, and Erik Brynjolfsson. 1996. "Could the Internet balkanize science?" Science 274, no. 5292: 1479-1480.

Varian, Hal R. 2010. "Computer mediated transactions." American Economic Review 100, no. 2: $1-10$.

Vigdor, Jacob L., and Helen F. Ladd. 2010. "Scaling the digital divide: Home computer technology and student achievement." NBER Working Paper 16078. Cambridge, MA: National Bureau of Economic Research. 


\section{Appendix}

Figure A1: Distance to main distribution frame: OPAL and non-OPAL

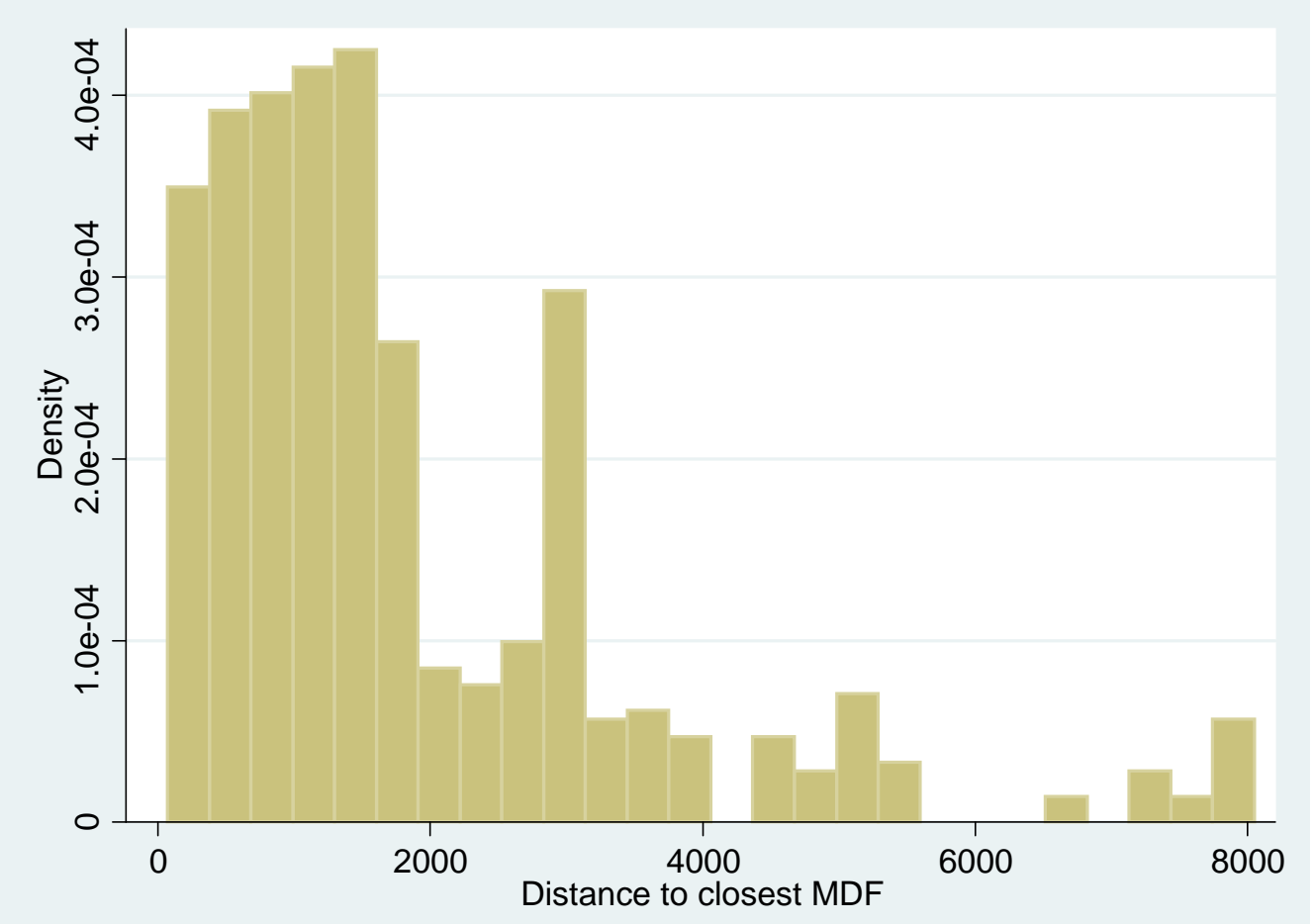

a) Distance if closest MDF is (formerly) OPAL (mean=1,850; $N=690$ )

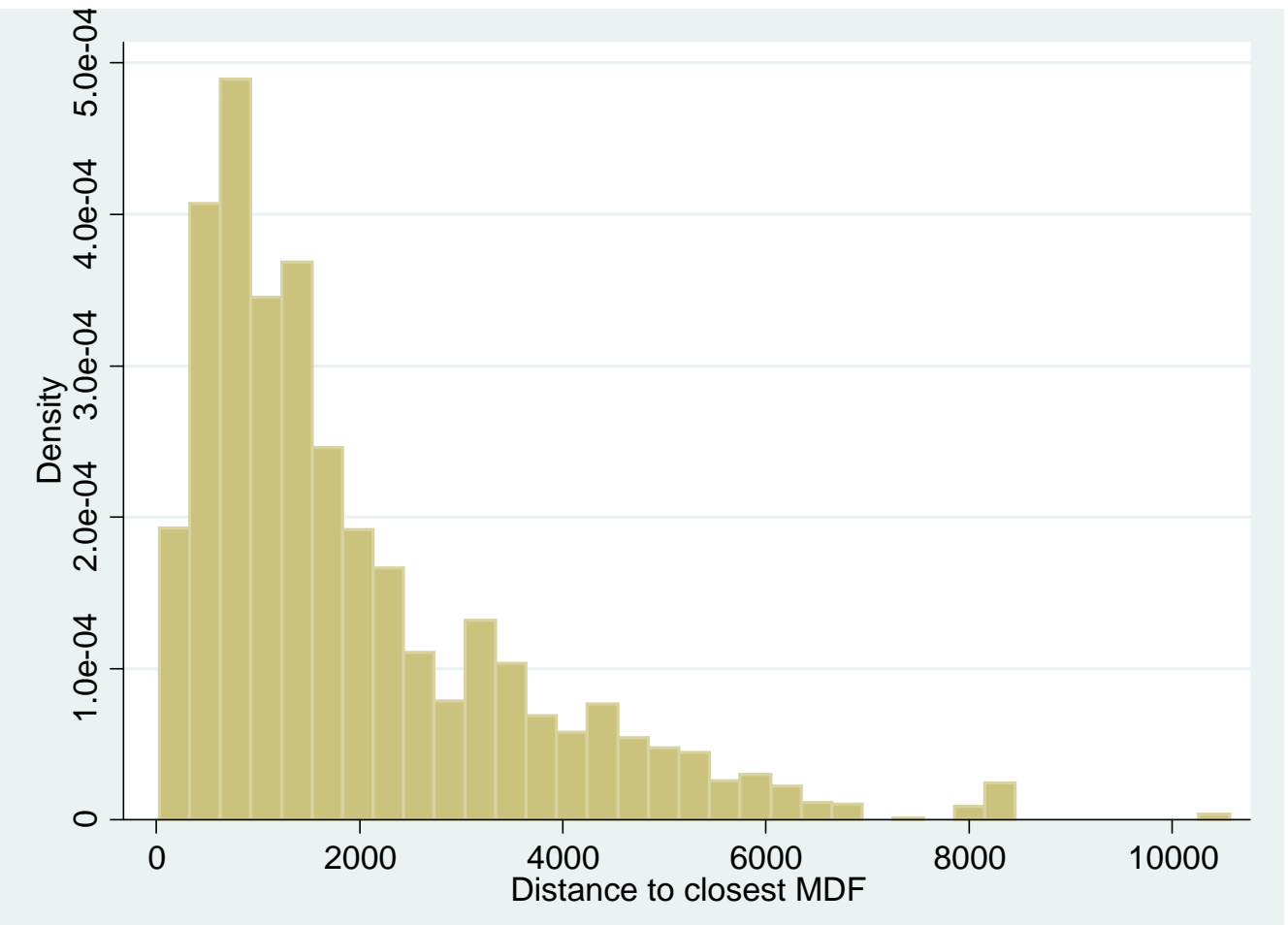

b) Distance if closest MDF is non-OPAL (mean=1,943; $N=3,426$ )

Notes: Histograms of distance (in meters) to main distribution frame (MDF) to which East German households are connected. Sample: all individuals in GSOEP 2008 living in East Germany. Data: GSOEP 2008. 
Figure A2: Structure of broadband network

Access Network

Backbone

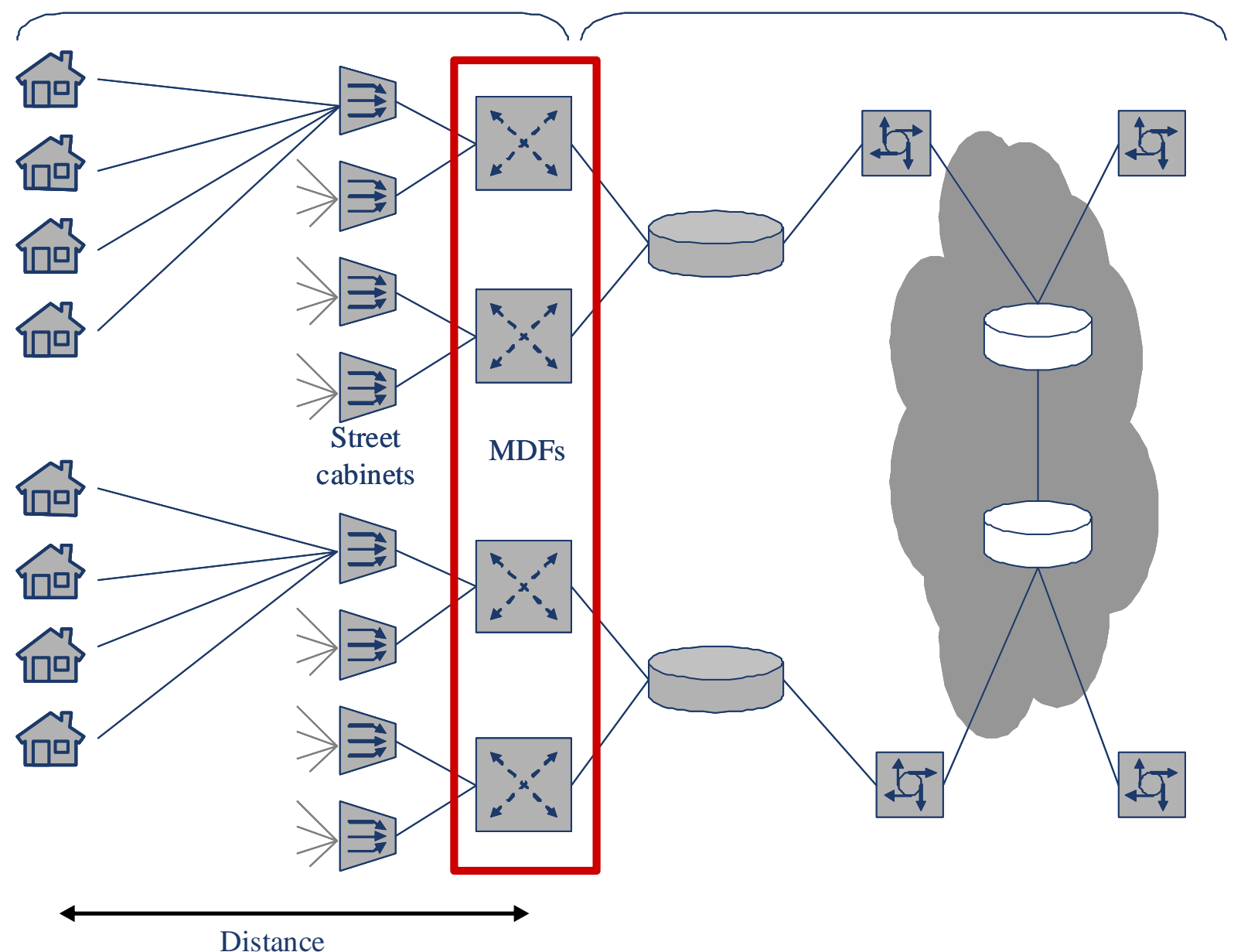

Notes: MDF = main distribution frame. Source: Anell, Jay, and Plueckebaum (2007). 
Table A1: The association between broadband Internet access and social capital: Marginal effects from ordered logit models

\begin{tabular}{|c|c|c|c|c|c|c|c|c|}
\hline & $\begin{array}{l}\text { Theater, opera, } \\
\text { and exhibitions }\end{array}$ & $\begin{array}{c}\text { Cinema } \\
\text { and concert }\end{array}$ & $\begin{array}{l}\text { Restaurant } \\
\text { and bar }\end{array}$ & $\begin{array}{c}\text { Visit } \\
\text { friends }\end{array}$ & $\begin{array}{l}\text { Volunteer } \\
\text { work }\end{array}$ & $\begin{array}{c}\text { Political } \\
\text { engagement }\end{array}$ & & $\begin{array}{l}\text { Interest in } \\
\text { politics }\end{array}$ \\
\hline \multirow[t]{2}{*}{ Never } & $-0.054^{* * *}$ & $-0.050^{* * *}$ & $-0.004^{* * *}$ & -0.001 & -0.008 & -0.003 & Not at all & $-0.014^{* * *}$ \\
\hline & $(0.010)$ & $(0.008)$ & $(0.001)$ & $(0.001)$ & (0.007) & $(0.004)$ & & $(0.004)$ \\
\hline \multirow[t]{2}{*}{ Less often than once a month } & $0.034^{* * *}$ & 0.007 & $-0.028^{* * *}$ & -0.007 & 0.003 & 0.002 & Not strong & $-0.021^{* * *}$ \\
\hline & $(0.008)$ & $(0.008)$ & $(0.007)$ & $(0.005)$ & (0.003) & $(0.003)$ & & $(0.006)$ \\
\hline \multirow[t]{2}{*}{ At least once a month } & $0.019^{* * *}$ & $0.038^{* * *}$ & -0.005 & -0.006 & 0.002 & 0.001 & Strong & $0.027^{* * *}$ \\
\hline & $(0.004)$ & $(0.006)$ & $(0.004)$ & $(0.004)$ & $(0.002)$ & $(0.001)$ & & $(0.007)$ \\
\hline \multirow[t]{2}{*}{ At least once a week } & $0.001^{* * *}$ & $0.006^{* * *}$ & $0.033^{* * *}$ & 0.012 & 0.003 & 0.000 & Very strong & $0.008^{* * *}$ \\
\hline & $(0.000)$ & $(0.001)$ & $(0.008)$ & $(0.008)$ & $(0.002)$ & $(0.000)$ & & $(0.002)$ \\
\hline \multirow[t]{2}{*}{ Every day } & 0.000 & $0.000^{* * *}$ & $0.003^{* * *}$ & 0.002 & 0.000 & 0.000 & & \\
\hline & $(0.000)$ & $(0.000)$ & $(0.001)$ & $(0.002)$ & $(0.000)$ & $(0.000)$ & & \\
\hline$N$ & 17,965 & 17,944 & 17,961 & 17,925 & 17,935 & 17,909 & & 17,952 \\
\hline Wald $\chi^{2}$ & 2,849 & 5,052 & 3,077 & 1,554 & 1,040 & 621 & & 4,014 \\
\hline Prob $>\chi^{2}$ & 0.000 & 0.000 & 0.000 & 0.000 & 0.000 & 0.000 & & 0.000 \\
\hline
\end{tabular}

Marginal effects of broadband Internet access (DSL) at home from ordered logit regressions, holding other variables constant at their mean. Dependent variable reported on top of each column. Sample: all individuals in GSOEP 2008. Additional controls included in each model: the individual's gender, age (and its square), marital status, number of children living in the household, secondary and university education, occupational status, migration background, a dummy indicating house/flat ownership, log net household income, and sixteen federal state dummies. Robust standard errors clustered at the household level in parentheses. ${ }^{* * *} 1 \%$, ${ }^{* *} 5 \%$, and ${ }^{*} 10 \%$ level of significance. Data source: GSOEP 2008 
Table A2: Broadband Internet access and social capital: Value-added models for East German sample

\begin{tabular}{|c|c|c|c|c|c|c|c|}
\hline & $\begin{array}{l}\text { Theater, opera, } \\
\text { and exhibitions }\end{array}$ & $\begin{array}{c}\text { Cinema } \\
\text { and concert }\end{array}$ & $\begin{array}{l}\text { Restaurant } \\
\text { and bar }\end{array}$ & $\begin{array}{l}\text { Visit } \\
\text { friends }\end{array}$ & $\begin{array}{l}\text { Volunteer } \\
\text { work }\end{array}$ & $\begin{array}{c}\text { Political } \\
\text { engagement }\end{array}$ & $\begin{array}{c}\text { Interest in } \\
\text { politics }\end{array}$ \\
\hline \multirow[t]{2}{*}{ Broadband Internet access (DSL) at home } & 0.049 & $0.083^{* *}$ & -0.018 & -0.003 & -0.023 & 0.048 & $0.061^{*}$ \\
\hline & $(0.043)$ & $(0.041)$ & $(0.046)$ & $(0.046)$ & $(0.042)$ & $(0.043)$ & $(0.036)$ \\
\hline \multirow[t]{2}{*}{ Social capital variable 2001} & $0.313^{* * *}$ & $0.276^{* * *}$ & $0.141^{* * *}$ & $0.282^{* * *}$ & $0.500^{* * *}$ & $0.421^{* * *}$ & $0.542^{* * *}$ \\
\hline & $(0.022)$ & $(0.024)$ & $(0.021)$ & $(0.021)$ & $(0.025)$ & $(0.046)$ & $(0.018)$ \\
\hline Individual-level controls & Yes & Yes & Yes & Yes & Yes & Yes & Yes \\
\hline$N$ & 2,816 & 2,813 & 2,818 & 2,811 & 2,796 & 2,787 & 2,818 \\
\hline$R^{2}$ & 0.262 & 0.385 & 0.174 & 0.156 & 0.290 & 0.212 & 0.428 \\
\hline
\end{tabular}

OLS regressions. Dependent variable (z-standardized) reported on top of each column. Variables refer to 2008 unless noted otherwise. Sample: all individuals in GSOEP 2008 living in East Germany with available information on the respective social capital variable also in GSOEP 2001. Additional controls included in each model: the individual's gender, age (and its square), marital status, number of children living in the household, secondary and university education, occupational status, migration background, a dummy indicating house/flat ownership, log net household income, and five federal state dummies. Robust standard errors clustered at the household level in parentheses.

$1 \%,{ }^{* *} 5 \%$, and ${ }^{*} 10 \%$ level of significance. Data source: GSOEP 2001 and 2008. 
Table A3: Broadband Internet access and social capital: IV results for subsample dropping non-OPAL households far from MDF

\begin{tabular}{|c|c|c|c|c|c|c|c|c|}
\hline & \multirow{2}{*}{$\begin{array}{c}1^{\text {st }} \text { stage } \\
\text { Broadband } \\
\text { Internet access }\end{array}$} & \multicolumn{7}{|c|}{$2^{\text {nd }}$ stage } \\
\hline & & $\begin{array}{l}\text { Theater, opera, } \\
\text { and exhibitions }\end{array}$ & $\begin{array}{c}\text { Cinema } \\
\text { and concert }\end{array}$ & $\begin{array}{l}\text { Restaurant } \\
\text { and bar }\end{array}$ & $\begin{array}{l}\text { Visit } \\
\text { friends }\end{array}$ & $\begin{array}{l}\text { Volunteer } \\
\text { work }\end{array}$ & $\begin{array}{c}\text { Political } \\
\text { engagement }\end{array}$ & $\begin{array}{l}\text { Interest in } \\
\text { politics }\end{array}$ \\
\hline OPAL access area in 1998 & $\begin{array}{c}-0.121^{* * *} \\
(0.028)\end{array}$ & & & & & & & \\
\hline Broadband Internet access (DSL) at home & & $\begin{array}{l}0.746^{* *} \\
(0.380)\end{array}$ & $\begin{array}{c}0.088 \\
(0.412)\end{array}$ & $\begin{array}{c}0.136 \\
(0.455)\end{array}$ & $\begin{array}{c}0.496 \\
(0.461)\end{array}$ & $\begin{array}{c}0.214 \\
(0.406)\end{array}$ & $\begin{array}{c}0.317 \\
(0.401)\end{array}$ & $\begin{array}{c}0.199 \\
(0.339)\end{array}$ \\
\hline County-level controls & Yes & Yes & Yes & Yes & Yes & Yes & Yes & Yes \\
\hline Individual-level controls & Yes & Yes & Yes & Yes & Yes & Yes & Yes & Yes \\
\hline $1^{\text {st }}$-stage $F$-statistic of excluded instrument & & 19.36 & 18.23 & 18.49 & 18.40 & 18.40 & 19.80 & 18.84 \\
\hline Robust exogeneity test: F-statistic & & 3.457 & 0.001 & 0.163 & 1.120 & 0.407 & 0.469 & 0.167 \\
\hline$p$-value & & 0.064 & 0.975 & 0.687 & 0.291 & 0.524 & 0.494 & 0.683 \\
\hline$N$ & 2,409 & 2,409 & 2,406 & 2,411 & 2,404 & 2,391 & 2,385 & 2,413 \\
\hline$R^{2}$ & 0.243 & 0.180 & 0.396 & 0.175 & 0.117 & 0.287 & 0.190 & 0.436 \\
\hline
\end{tabular}

Subsample of individuals who live in households in (former) OPAL areas or in households in non-OPAL areas whose distance to the closest main distribution frame (MDF) is not more than 3.5 kilometers. 2SLS regressions. Dependent variable reported on top of each column. The first column reports first-stage results; the other columns report second-stage results of separate 2SLS regressions. Variables refer to 2008 unless noted otherwise. Base sample: all individuals in GSOEP 2008 living in East Germany with available information on the respective social capital variable also in GSOEP 2001. Additional controls included in each model: $z$-standardized lagged outcome variable measured in 2001, the individual's gender, age (and its square), marital status, number of children living in the household, secondary and university education, occupational status, migration background, a dummy indicating house/flat ownership, log net household income, population density of county in 1995, GDP per capita of county in 1995, and five federal state dummies. Robust standard errors clustered at the level of the telephone access area in parentheses. ${ }^{* * *} 1 \%$, ${ }^{* *} 5 \%$, and ${ }^{*} 10 \%$ level of significance. Data source: GSOEP 2001 and 2008. 
Figure 1: Distance to main distribution frame

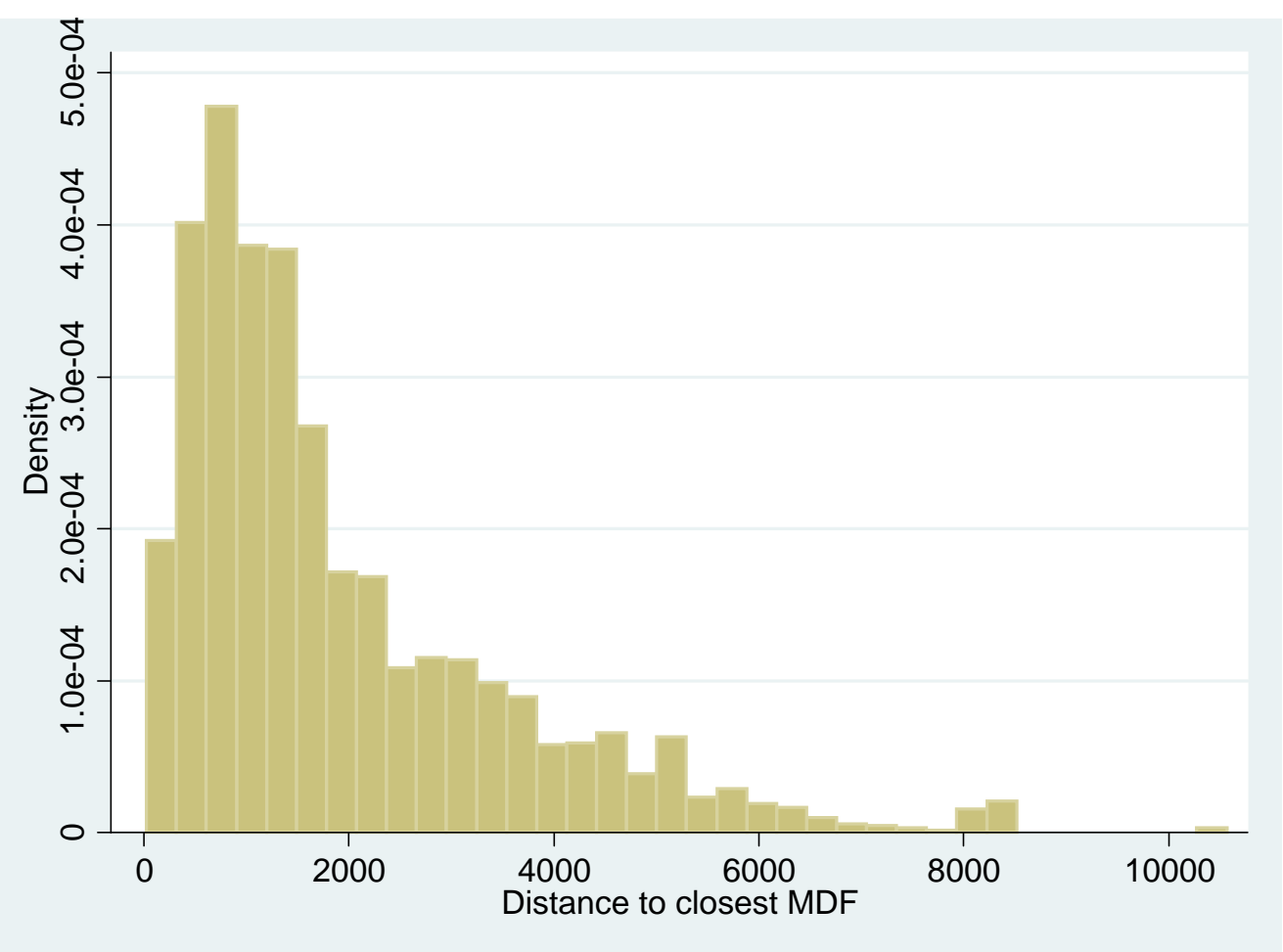

Notes: Histogram of distance (in meters) to main distribution frame (MDF) to which East German households are connected. Sample: all individuals in GSOEP 2008 living in East Germany. Data: GSOEP 2008. 
Table 1: Descriptive statistics

\begin{tabular}{|c|c|c|c|c|}
\hline & & $\begin{array}{c}\text { OLS } \\
\text { sample }\end{array}$ & $\begin{array}{l}\text { Value-added } \\
\text { sample }\end{array}$ & $\begin{array}{l}\text { 2SLS value- } \\
\text { added sample }\end{array}$ \\
\hline \multirow[t]{2}{*}{$\begin{array}{l}\text { Broadband Internet access } \\
\text { (DSL) at home }\end{array}$} & Yes & $\begin{array}{c}0.56 \\
{[10,552]}\end{array}$ & $\begin{array}{c}0.50 \\
{[6,481]}\end{array}$ & $\begin{array}{c}0.38 \\
{[1,141]}\end{array}$ \\
\hline & No & $\begin{array}{c}0.44 \\
{[8,330]}\end{array}$ & $\begin{array}{c}0.50 \\
{[6,359]}\end{array}$ & $\begin{array}{c}0.62 \\
{[1,841]}\end{array}$ \\
\hline \multirow[t]{2}{*}{ Gender } & Male & $\begin{array}{c}0.48 \\
{[8,991]}\end{array}$ & $\begin{array}{c}0.47 \\
{[6,029]}\end{array}$ & $\begin{array}{c}0.47 \\
{[1,413]}\end{array}$ \\
\hline & Female & $\begin{array}{c}0.52 \\
{[9,891]}\end{array}$ & $\begin{array}{c}0.53 \\
{[6,811]}\end{array}$ & $\begin{array}{c}0.53 \\
{[1,570]}\end{array}$ \\
\hline \multirow[t]{3}{*}{ Marital status } & Married & $\begin{array}{c}0.61 \\
{[11,587]}\end{array}$ & $\begin{array}{c}0.67 \\
{[8,657]}\end{array}$ & $\begin{array}{c}0.65 \\
{[1,947]}\end{array}$ \\
\hline & Single & $\begin{array}{c}0.32 \\
{[6,020]}\end{array}$ & $\begin{array}{c}0.24 \\
{[3,136]}\end{array}$ & $\begin{array}{c}0.27 \\
{[797]}\end{array}$ \\
\hline & Widowed & $\begin{array}{c}0.07 \\
{[1,275]}\end{array}$ & $\begin{array}{c}0.08 \\
{[1,047]}\end{array}$ & $\begin{array}{c}0.08 \\
{[239]}\end{array}$ \\
\hline \multirow[t]{5}{*}{ Schooling } & No or lower secondary & $\begin{array}{c}0.35 \\
{[6,379]}\end{array}$ & $\begin{array}{c}0.40 \\
{[5,029]}\end{array}$ & $\begin{array}{c}0.31 \\
{[900]}\end{array}$ \\
\hline & Medium secondary & $\begin{array}{c}0.30 \\
{[5,482]}\end{array}$ & $\begin{array}{c}0.31 \\
{[3,859]}\end{array}$ & $\begin{array}{c}0.47 \\
{[1,388]}\end{array}$ \\
\hline & Higher secondary & $\begin{array}{c}0.27 \\
{[4,906]}\end{array}$ & $\begin{array}{c}0.23 \\
{[2,863]}\end{array}$ & $\begin{array}{c}0.20 \\
{[597]}\end{array}$ \\
\hline & Other & $\begin{array}{c}0.06 \\
{[1,091]}\end{array}$ & $\begin{array}{c}0.06 \\
{[778]}\end{array}$ & $\begin{array}{l}0.02 \\
{[50]}\end{array}$ \\
\hline & Pupil & $\begin{array}{c}0.02 \\
{[343]}\end{array}$ & $\begin{array}{c}0.00 \\
{[1]}\end{array}$ & $\begin{array}{c}0.00 \\
{[0]}\end{array}$ \\
\hline \multirow[t]{3}{*}{ University education } & No & $\begin{array}{c}0.79 \\
{[14,696]}\end{array}$ & $\begin{array}{c}0.80 \\
{[10,245]}\end{array}$ & $\begin{array}{c}0.74 \\
{[2,183]}\end{array}$ \\
\hline & Univ. of Applied Sciences & $\begin{array}{c}0.09 \\
{[1,640]}\end{array}$ & $\begin{array}{c}0.09 \\
{[1,133]}\end{array}$ & $\begin{array}{c}0.15 \\
{[434]}\end{array}$ \\
\hline & University & $\begin{array}{c}0.13 \\
{[2,360]}\end{array}$ & $\begin{array}{c}0.11 \\
{[1,358]}\end{array}$ & $\begin{array}{c}0.12 \\
{[347]}\end{array}$ \\
\hline
\end{tabular}

(to be continued) 
Table 1 (continued)

\begin{tabular}{|c|c|c|c|c|}
\hline & & $\begin{array}{c}\text { OLS } \\
\text { sample }\end{array}$ & $\begin{array}{l}\text { Value-added } \\
\text { sample }\end{array}$ & $\begin{array}{l}\text { 2SLS value- } \\
\text { added sample }\end{array}$ \\
\hline \multirow[t]{14}{*}{ Occupational status } & \multirow[t]{2}{*}{ Non-working } & 0.06 & 0.06 & 0.02 \\
\hline & & {$[1,187]$} & [820] & [73] \\
\hline & \multirow[t]{2}{*}{ Apprentice } & 0.07 & 0.02 & 0.02 \\
\hline & & {$[1,370]$} & [206] & {$[45]$} \\
\hline & \multirow[t]{2}{*}{ Unemployed } & 0.05 & 0.05 & 0.09 \\
\hline & & [951] & [655] & [259] \\
\hline & \multirow[t]{2}{*}{ Retired } & 0.27 & 0.31 & 0.35 \\
\hline & & {$[4,973]$} & {$[3,956]$} & {$[1,026]$} \\
\hline & \multirow[t]{2}{*}{ Blue collar worker } & 0.16 & 0.18 & 0.18 \\
\hline & & {$[2,975]$} & {$[2,233]$} & {$[540]$} \\
\hline & \multirow[t]{2}{*}{ White collar worker } & 0.33 & 0.33 & 0.28 \\
\hline & & {$[6,164]$} & {$[4,161]$} & [841] \\
\hline & \multirow{2}{*}{ Entrepreneur } & 0.06 & 0.06 & 0.06 \\
\hline & & {$[1,117]$} & {$[724]$} & {$[177]$} \\
\hline \multirow[t]{6}{*}{ Migration background } & \multirow[t]{2}{*}{ None } & 0.85 & 0.84 & 0.98 \\
\hline & & {$[16,043]$} & {$[10,843]$} & {$[2,912]$} \\
\hline & \multirow[t]{2}{*}{ Direct } & 0.10 & 0.12 & 0.01 \\
\hline & & {$[1,980]$} & {$[1,477]$} & {$[32]$} \\
\hline & \multirow[t]{2}{*}{ Indirect } & 0.05 & 0.04 & 0.01 \\
\hline & & [859] & {$[520]$} & [39] \\
\hline \multirow[t]{4}{*}{ Owner of a house/flat } & \multirow[t]{2}{*}{ Yes } & 0.55 & 0.54 & 0.48 \\
\hline & & {$[10,293]$} & {$[6,928]$} & {$[1,443]$} \\
\hline & \multirow[t]{2}{*}{ No } & 0.45 & 0.46 & 0.52 \\
\hline & & {$[8,589]$} & {$[5,912]$} & {$[1,539]$} \\
\hline \multirow[t]{3}{*}{ Age } & Mean & 49.41 & 53.08 & 53.65 \\
\hline & Std. dev. & 17.65 & 15.89 & 15.78 \\
\hline & $N$ & {$[18,882]$} & {$[12,840]$} & {$[2,983]$} \\
\hline \multirow[t]{3}{*}{ Children in household } & Mean & 0.44 & 0.43 & 0.30 \\
\hline & Std. dev. & 0.83 & 0.83 & 0.69 \\
\hline & $N$ & {$[18,882]$} & {$[12,840]$} & {$[2,983]$} \\
\hline \multirow{3}{*}{$\begin{array}{l}\text { Net household income } \\
\text { per month (in } € \text { ) }\end{array}$} & Mean & 3,062 & 2,746 & 2,367 \\
\hline & Std. dev. & 2,237 & 1,577 & 1,264 \\
\hline & $N$ & {$[18,882]$} & {$[12,840]$} & {$[2,983]$} \\
\hline
\end{tabular}

Percentage shares unless otherwise noted. Number of observations in square brackets. Samples: OLS: all individuals in GSOEP 2008; value-added: all individuals in GSOEP 2008 with available information on social capital in GSOEP 2001; 2SLS value-added: all individuals in GSOEP 2008 living in East Germany with available information on social capital in GSOEP 2001. Data source: GSOEP 2008. 
Table 2: Descriptive statistics: measures of social capital

\begin{tabular}{|c|c|c|c|c|c|c|c|c|}
\hline & $\begin{array}{l}\text { Theater, opera, } \\
\text { and exhibitions }\end{array}$ & $\begin{array}{c}\text { Cinema } \\
\text { and concert }\end{array}$ & $\begin{array}{l}\text { Restaurant } \\
\text { and bar }\end{array}$ & $\begin{array}{l}\text { Visit } \\
\text { friends }\end{array}$ & $\begin{array}{l}\text { Number } \\
\text { of friends }\end{array}$ & $\begin{array}{l}\text { Volunteer } \\
\text { work }\end{array}$ & $\begin{array}{c}\text { Political } \\
\text { engagement }\end{array}$ & $\begin{array}{l}\text { Interest in } \\
\text { politics }\end{array}$ \\
\hline \multicolumn{9}{|c|}{ OLS sample } \\
\hline Mean & 1.68 & 1.85 & 2.66 & 3.20 & 4.23 & 1.58 & 1.15 & 2.27 \\
\hline Std. dev. & 0.66 & 0.81 & 0.95 & 0.91 & 3.71 & 1.04 & 0.49 & 0.81 \\
\hline Min & 1 & 1 & 1 & 1 & 0 & 1 & 1 & 1 \\
\hline Max & 5 & 5 & 5 & 5 & 90 & 5 & 5 & 4 \\
\hline$N$ & 18,846 & 18,822 & 18,842 & 18,805 & 18,296 & 18,813 & 18,787 & 18,831 \\
\hline \multicolumn{9}{|c|}{ Value-added sample } \\
\hline Mean & 1.63 & 1.72 & 2.55 & 3.11 & 4.03 & 1.56 & 1.14 & 2.25 \\
\hline Std. dev. & 0.64 & 0.74 & 0.93 & 0.91 & 3.56 & 1.01 & 0.47 & 0.79 \\
\hline$N$ & 12,817 & 12,802 & 12,810 & 12,786 & 12,404 & 12,791 & 12,774 & 12,799 \\
\hline \multicolumn{9}{|c|}{ 2SLS value-added sample } \\
\hline Mean & 1.62 & 1.71 & 2.29 & 2.99 & 4.08 & 1.45 & 1.13 & 2.21 \\
\hline Std. dev. & 0.61 & 0.70 & 0.83 & 0.90 & 3.48 & 0.91 & 0.45 & 0.78 \\
\hline$N$ & 2,978 & 2,977 & 2,979 & 2,972 & 2,831 & 2,969 & 2,966 & 2,981 \\
\hline
\end{tabular}

All variables coded in a way that higher values correspond to higher intensity. Samples: OLS: all individuals in GSOEP 2008; value-added: all individuals in GSOEP 2008 with available information on the respective social capital variable in GSOEP 2001; 2SLS value-added: all individuals in GSOEP 2008 living in East Germany with available information on the respective social capital variable in GSOEP 2001. "Number of friends": count variable. "Interest in politics": four-point scale running from 1 ("not interested at all") to 4 ("very strong"). All other variables are categorical variables where individuals rank the frequency of the respective social activity, where 1 means “never”, 2 "less often than once a month”, 3 “at least once a month”, 4 “at least once a week”, and 5 “every day”. Data source: GSOEP 2008. 
Table 3: Description of the broadband Internet users

\begin{tabular}{|c|c|c|}
\hline & Dependent variable: & Broadband Internet access (DSL) at home \\
\hline Female & & $-0.032^{* * *}(0.007)$ \\
\hline Age & & $0.006^{* * *}(0.001)$ \\
\hline $\operatorname{Age}^{2}(/ 100)$ & & $-0.013^{* * *}(0.001)$ \\
\hline \multicolumn{3}{|l|}{ Marital status (omitted category: married) } \\
\hline Single & & $-0.052^{* * *}(0.010)$ \\
\hline Widowed & & $-0.019(0.013)$ \\
\hline Number of children in household & & $0.010^{* *}(0.004)$ \\
\hline \multicolumn{3}{|c|}{ Schooling (omitted category: None/lower secondary) } \\
\hline Medium secondary & & $0.074^{* * *}(0.009)$ \\
\hline Higher secondary & & $0.111^{* * *}(0.011)$ \\
\hline Other & & $0.009(0.017)$ \\
\hline Pupil & & $0.140^{* * *}(0.026)$ \\
\hline \multicolumn{3}{|c|}{ University education (omitted category: None) } \\
\hline University of Applied Sciences & & $0.040^{* * *}(0.012)$ \\
\hline University & & $0.031^{* *}(0.012)$ \\
\hline \multicolumn{3}{|c|}{ Occupational status (omitted category: non-working) } \\
\hline Apprentice & & $0.039^{*}(0.022)$ \\
\hline Unemployed & & $-0.008(0.021)$ \\
\hline Retired & & $-0.065^{* * *}(0.018)$ \\
\hline Blue collar worker & & $-0.035^{* *}(0.017)$ \\
\hline White collar worker & & $0.035^{* *}(0.015)$ \\
\hline Entrepreneur & & $0.036^{*}(0.019)$ \\
\hline \multicolumn{3}{|c|}{ Migration background (omitted category: none) } \\
\hline Direct & & $-0.045^{* * *}(0.013)$ \\
\hline Indirect & & $-0.031^{*}(0.016)$ \\
\hline House/flat ownership & & $0.024^{* * *}(0.007)$ \\
\hline Log net household income & & $0.181^{* * *}(0.007)$ \\
\hline Federal state dummies (16) & & Yes \\
\hline$N$ & & 17,997 \\
\hline$R^{2}$ & & 0.279 \\
\hline
\end{tabular}

OLS regressions. Sample: all individuals in GSOEP 2008. Robust standard errors clustered at the household level in parentheses.

*** $1 \%,{ }^{* *} 5 \%$, and ${ }^{*} 10 \%$ level of significance. Data source: GSOEP 2008. 
Table 4: The association between broadband Internet access and social capital

\begin{tabular}{|c|c|c|c|c|c|c|c|c|}
\hline & $\begin{array}{l}\text { Theater, opera, } \\
\text { and exhibitions }\end{array}$ & $\begin{array}{c}\text { Cinema } \\
\text { and concert }\end{array}$ & $\begin{array}{l}\text { Restaurant } \\
\text { and bar }\end{array}$ & $\begin{array}{l}\text { Visit } \\
\text { friends }\end{array}$ & $\begin{array}{l}\text { Number } \\
\text { of friends }\end{array}$ & $\begin{array}{l}\text { Volunteer } \\
\text { work }\end{array}$ & $\begin{array}{c}\text { Political } \\
\text { engagement }\end{array}$ & $\begin{array}{l}\text { Interest in } \\
\text { politics }\end{array}$ \\
\hline $\begin{array}{l}\text { Broadband Internet access } \\
\text { (DSL) at home }\end{array}$ & $0.101^{* * *}(0.019)$ & $0.106^{* * *}(0.017)$ & $0.077^{* * *}(0.019)$ & $0.030(0.020)$ & $0.037^{*}(0.020)$ & $0.038^{* *}(0.019)$ & $0.024(0.019)$ & $0.070^{* * *}(0.017)$ \\
\hline Female & $0.174^{* * *}(0.012)$ & $0.004(0.011)$ & $-0.147^{* * *}(0.012)$ & $0.070^{* * *}(0.013)$ & $-0.037^{* * *}(0.014)$ & $-0.138^{* * *}(0.014)$ & $-0.145^{* * *}(0.014)$ & $-0.383^{* * *}(0.013)$ \\
\hline Age & $0.033^{* * *}(0.003)$ & $-0.042^{* * * *}(0.003)$ & $-0.015^{* * * *}(0.003)$ & $-0.040^{* * *}(0.004)$ & $-0.015^{* * *}(0.003)$ & $0.015^{* * *}(0.003)$ & $0.012^{* * *}(0.003)$ & $0.028^{* * *}(0.003)$ \\
\hline $\operatorname{Age}^{2}(/ 100)$ & $-0.026^{* * * *}(0.003)$ & $0.019^{* * * *}(0.003)$ & $0.003(0.003)$ & $0.022^{* * *}(0.004)$ & $0.013^{* * *}(0.003)$ & $-0.015^{* * *}(0.003)$ & $-0.007^{* *}(0.003)$ & $-0.014^{* * *}(0.003)$ \\
\hline \multicolumn{9}{|l|}{ Marital status } \\
\hline Single & $0.134^{* * *}(0.021)$ & $0.212^{* * *}(0.019)$ & $0.232^{* * *}(0.022)$ & $0.092^{* * *}(0.023)$ & $-0.011(0.021)$ & $-0.053^{* *}(0.022)$ & $-0.006(0.022)$ & $0.068^{* * *}(0.020)$ \\
\hline Widowed & $-0.007(0.035)$ & $0.036(0.024)$ & $0.206^{* * *}(0.035)$ & $0.194^{* * *}(0.039)$ & $-0.080^{*}(0.042)$ & $0.001(0.032)$ & $-0.056^{*}(0.034)$ & $0.038(0.033)$ \\
\hline No. children in household & $-0.079^{* * * *}(0.010)$ & $-0.117^{* * *}(0.010)$ & $-0.158^{* * *}(0.011)$ & $-0.013(0.012)$ & $-0.043^{* * *}(0.012)$ & $0.026^{* *}(0.011)$ & $-0.003(0.011)$ & $-0.011(0.010)$ \\
\hline \multicolumn{9}{|l|}{ Schooling } \\
\hline Medium secondary & $0.269^{* * *}(0.020)$ & $0.137^{* * *}(0.017)$ & $0.072^{* * *}(0.019)$ & $0.060^{* * *}(0.021)$ & $0.077^{* * *}(0.021)$ & $0.053^{* * *}(0.020)$ & $0.055^{* * *}(0.019)$ & $0.250^{* * *}(0.019)$ \\
\hline Higher secondary & $0.427^{* * *}(0.026)$ & $0.202^{* * *}(0.023)$ & $0.148^{* * *}(0.024)$ & $0.084^{* * *}(0.025)$ & $0.119^{* * *}(0.027)$ & $0.113^{* * *}(0.028)$ & $0.122^{* * *}(0.029)$ & $0.476^{* * *}(0.024)$ \\
\hline Other & $0.022(0.036)$ & $-0.038(0.033)$ & $-0.121^{* * *}(0.039)$ & $-0.038(0.042)$ & $0.036(0.044)$ & $-0.079^{* *}(0.032)$ & $0.024(0.034)$ & $0.041(0.037)$ \\
\hline Pupil & $0.478^{* * *}(0.064)$ & $0.109(0.068)$ & $-0.115^{*}(0.060)$ & $0.088(0.060)$ & $0.244^{* * *}(0.094)$ & $0.231^{* * *}(0.078)$ & $0.163^{* *}(0.065)$ & $0.379^{* * *}(0.064)$ \\
\hline \multicolumn{9}{|l|}{ University education } \\
\hline Univ. of Applied Sciences & $0.224^{* * * *}(0.028)$ & $0.095^{* * *}(0.024)$ & $0.103^{* * *}(0.025)$ & $0.059^{* *}(0.026)$ & $-0.020(0.028)$ & $0.133^{* * *}(0.031)$ & $0.056^{*}(0.033)$ & $0.182^{* * * *}(0.026)$ \\
\hline University & $0.429^{* * *}(0.029)$ & $0.104^{* * *}(0.025)$ & $0.129^{* * *}(0.026)$ & $0.066^{* *}(0.027)$ & $0.078^{* * *}(0.030)$ & $0.112^{* * *}(0.032)$ & $0.149^{* * *}(0.038)$ & $0.338^{* * *}(0.027)$ \\
\hline \multicolumn{9}{|l|}{ Occupational status } \\
\hline Apprentice & $0.242^{* * *}(0.048)$ & $0.334^{* * *}(0.048)$ & $0.013(0.046)$ & $-0.159^{* * *}(0.047)$ & $0.136^{* *}(0.058)$ & $0.161^{* * * *}(0.051)$ & 0.0 & $0.168^{* * *}(0.046)$ \\
\hline Unemployed & $-0.100^{* * *}(0.038)$ & $-0.059(0.038)$ & $-0.261^{* * *}(0.044)$ & $-0.140^{* * *}(0.050)$ & $-0.054(0.045)$ & $-0.084^{* *}(0.041)$ & $-0.023(0.037)$ & $-0.046(0.042)$ \\
\hline Retired & $0.138^{* * * *}(0.037)$ & $0.100^{* * * *}(0.032)$ & $0.152^{* * *}(0.037)$ & $0.048(0.040)$ & $0.043(0.037)$ & $-0.004(0.039)$ & $-0.056(0.039)$ & $0.108^{* * *}(0.036)$ \\
\hline Blue collar worker & $-0.090^{* * * *}(0.031)$ & $0.109^{* * * *}(0.029)$ & $-0.080^{* *}(0.033)$ & $-0.163^{* * * *}(0.036)$ & $-0.015(0.033)$ & $-0.062^{*}(0.035)$ & $-0.044(0.032)$ & $-0.092^{* * *}(0.032)$ \\
\hline White collar worker & $0.038(0.030)$ & $0.239^{* * *}(0.027)$ & $0.071^{* *}(0.030)$ & $-0.169^{* * *}(0.032)$ & $-0.018(0.030)$ & $-0.008(0.033)$ & $0.018(0.030)$ & $0.061^{* *}(0.029)$ \\
\hline Entrepreneur & $0.089^{* *}(0.039)$ & $0.222^{* * *}(0.036)$ & $0.191^{* * *}(0.040)$ & $-0.164^{* * *}(0.040)$ & $0.047(0.045)$ & $0.044(0.046)$ & $0.120^{* *}(0.049)$ & $0.110^{* * *}(0.038)$ \\
\hline \multicolumn{9}{|l|}{ Migration background } \\
\hline Direct & $-0.153^{* * * *}(0.029)$ & $-0.071^{* *}(0.028)$ & $-0.140^{* * * *}(0.031)$ & $0.151^{* * *}(0.032)$ & $0.018(0.032)$ & $-0.242^{* * * *}(0.028)$ & $-0.065^{* *}(0.028)$ & $-0.215^{* * *}(0.030)$ \\
\hline Indirect & $-0.008(0.037)$ & $0.030(0.034)$ & $0.010(0.037)$ & 0.062 (0.039) & $0.054(0.047)$ & $-0.108^{* * *}(0.038)$ & $-0.042(0.032)$ & $-0.094^{* * *}(0.034)$ \\
\hline House/flat ownership & $-0.062^{* * *}(0.018)$ & $-0.014(0.015)$ & $0.020(0.018)$ & $-0.079^{* * *}(0.019)$ & $-0.094^{* * *}(0.019)$ & $-0.176^{* * *}(0.018)$ & $-0.094^{* * *}(0.017)$ & $-0.015(0.016)$ \\
\hline Log net household income & $0.262^{* * * *}(0.018)$ & $0.193^{* * *}(0.016)$ & $0.347^{* * *}(0.018)$ & $-0.012(0.018)$ & $0.076^{* * *}(0.019)$ & $0.033^{*}(0.018)$ & $0.056^{* * *}(0.020)$ & $0.140^{* * *}(0.017)$ \\
\hline Federal state dummies (16) & Yes & Yes & Yes & Yes & Yes & Yes & Yes & Yes \\
\hline $\bar{N}$ & 17,965 & 17,944 & 17,961 & 17,925 & 17,452 & 17,935 & 17,909 & 17,952 \\
\hline$R^{2}$ & 0.207 & 0.364 & 0.210 & 0.103 & 0.027 & 0.060 & 0.038 & 0.222 \\
\hline
\end{tabular}

OLS regressions. Dependent variable (z-standardized) reported on top of each column. Sample: all individuals in GSOEP 2008. Robust standard errors clustered at the household level in parentheses. ${ }^{* * *} 1 \%,{ }^{* *} 5 \%$, and ${ }^{*} 10 \%$ level of significance. Data source: GSOEP 2008. 
Table 5: Broadband Internet access and social capital: Value-added models

\begin{tabular}{|c|c|c|c|c|c|c|c|}
\hline & $\begin{array}{l}\text { Theater, opera, } \\
\text { and exhibitions }\end{array}$ & $\begin{array}{c}\text { Cinema } \\
\text { and concert }\end{array}$ & $\begin{array}{l}\text { Restaurant } \\
\text { and bar }\end{array}$ & $\begin{array}{l}\text { Visit } \\
\text { friends }\end{array}$ & $\begin{array}{c}\text { Volunteer } \\
\text { work }\end{array}$ & $\begin{array}{c}\text { Political } \\
\text { engagement }\end{array}$ & $\begin{array}{c}\text { Interest in } \\
\text { politics }\end{array}$ \\
\hline \multirow[t]{2}{*}{ Broadband Internet access (DSL) at home } & $0.063^{* * *}$ & $0.093^{* * *}$ & $0.038^{*}$ & 0.009 & 0.019 & 0.031 & 0.020 \\
\hline & $(0.021)$ & $(0.020)$ & $(0.022)$ & $(0.022)$ & $(0.020)$ & $(0.021)$ & $(0.017)$ \\
\hline \multirow[t]{2}{*}{ Social capital variable 2001} & $0.353^{* * *}$ & $0.272^{* * *}$ & $0.145^{* * *}$ & $0.278^{* * *}$ & $0.487^{* * *}$ & $0.425^{* * *}$ & $0.514^{* * *}$ \\
\hline & $(0.010)$ & $(0.011)$ & $(0.010)$ & $(0.010)$ & $(0.011)$ & $(0.022)$ & $(0.009)$ \\
\hline Individual-level controls & Yes & Yes & Yes & Yes & Yes & Yes & Yes \\
\hline$N$ & 12,351 & 12,319 & 12,347 & 12,322 & 12,266 & 12,224 & 12,366 \\
\hline$R^{2}$ & 0.285 & 0.369 & 0.204 & 0.146 & 0.281 & 0.212 & 0.407 \\
\hline
\end{tabular}

OLS regressions. Dependent variable (z-standardized) reported on top of each column. Variables refer to 2008 unless noted otherwise. Sample: all individuals in GSOEP 2008 with available information on the respective social capital variable also in GSOEP 2001. Additional controls included in each model: the individual's gender, age (and its square), marital status, number of children living in the household, secondary and university education, occupational status, migration background, a dummy indicating house/flat ownership, log net household income, and sixteen federal state dummies. Robust standard errors clustered at the household level in parentheses. ${ }^{* * *} 1 \%$, ${ }^{* *} 5 \%$, and ${ }^{*}$ 10\% level of significance. Data source: GSOEP 2001 and 2008. 
Table 6: Broadband Internet access and social capital: Instrumental-variable results exploiting variation from a technological mistake

\begin{tabular}{|c|c|c|c|c|c|c|c|c|}
\hline & \multirow{2}{*}{$\begin{array}{c}1^{\text {st }} \text { stage } \\
\text { Broadband } \\
\text { Internet access }\end{array}$} & \multicolumn{7}{|c|}{$2^{\text {nd }}$ stage } \\
\hline & & $\begin{array}{l}\text { Theater, opera, } \\
\text { and exhibitions }\end{array}$ & $\begin{array}{c}\text { Cinema } \\
\text { and concert }\end{array}$ & $\begin{array}{c}\text { Restaurant } \\
\text { and bar }\end{array}$ & $\begin{array}{l}\text { Visit } \\
\text { friends }\end{array}$ & $\begin{array}{c}\text { Volunteer } \\
\text { work }\end{array}$ & $\begin{array}{c}\text { Political } \\
\text { engagement }\end{array}$ & $\begin{array}{c}\text { Interest in } \\
\text { politics }\end{array}$ \\
\hline OPAL access area in 1998 & $\begin{array}{c}-0.113^{* * *} \\
(0.027)\end{array}$ & & & & & & & \\
\hline Broadband Internet access (DSL) at home & & $\begin{array}{l}0.786^{*} \\
(0.411)\end{array}$ & $\begin{array}{c}0.098 \\
(0.456)\end{array}$ & $\begin{array}{c}0.099 \\
(0.483)\end{array}$ & $\begin{array}{c}0.583 \\
(0.495)\end{array}$ & $\begin{array}{c}0.284 \\
(0.440)\end{array}$ & $\begin{array}{c}0.273 \\
(0.419)\end{array}$ & $\begin{array}{c}0.335 \\
(0.369)\end{array}$ \\
\hline GDP per capita 1995 & $\begin{array}{c}0.003 \\
(0.005)\end{array}$ & $\begin{array}{c}0.000 \\
(0.010)\end{array}$ & $\begin{array}{c}0.005 \\
(0.007)\end{array}$ & $\begin{array}{c}0.013 \\
(0.008)\end{array}$ & $\begin{array}{c}0.010 \\
(0.007)\end{array}$ & $\begin{array}{c}-0.003 \\
(0.008)\end{array}$ & $\begin{array}{c}-0.004 \\
(0.006)\end{array}$ & $\begin{array}{c}-0.001 \\
(0.006)\end{array}$ \\
\hline Population density 1995 (/100) & $\begin{array}{c}0.003 \\
(0.003)\end{array}$ & $\begin{array}{c}0.012^{*} \\
(0.007)\end{array}$ & $\begin{array}{c}0.010^{*} \\
((0.006)\end{array}$ & $\begin{array}{c}0.001 \\
(0.006)\end{array}$ & $\begin{array}{c}-0.005 \\
(0.007)\end{array}$ & $\begin{array}{c}-0.004 \\
(0.007)\end{array}$ & $\begin{array}{c}-0.006 \\
(0.005)\end{array}$ & $\begin{array}{c}0.002 \\
(0.006)\end{array}$ \\
\hline Individual-level controls & Yes & Yes & Yes & Yes & Yes & Yes & Yes & Yes \\
\hline $1^{\text {st }}$-stage $F$-statistic of excluded instrument & & 17.47 & 16.48 & 16.81 & 16.73 & 16.97 & 18.06 & 17.14 \\
\hline Robust exogeneity test: F-statistic & & 3.399 & 0.002 & 0.063 & 1.414 & 0.523 & 0.295 & 0.599 \\
\hline$p$-value & & 0.066 & 0.964 & 0.801 & 0.235 & 0.470 & 0.587 & 0.439 \\
\hline$N$ & 2,816 & 2,816 & 2,813 & 2,818 & 2,811 & 2,796 & 2,787 & 2,818 \\
\hline$R^{2}$ & 0.237 & 0.166 & 0.388 & 0.173 & 0.093 & 0.274 & 0.204 & 0.415 \\
\hline
\end{tabular}

2SLS regressions. Dependent variable reported on top of each column. The first column reports first-stage results; the other columns report second-stage results of separate 2SLS regressions. Variables refer to 2008 unless noted otherwise. Sample: all individuals in GSOEP 2008 living in East Germany with available information on the respective social capital variable also in GSOEP 2001. Additional controls included in each model: z-standardized lagged outcome variable measured in 2001, the individual's gender, age (and its square), marital status, number of children living in the household, secondary and university education, occupational status, migration background, a dummy indicating house/flat ownership, log net household income, and five federal state dummies. Robust standard errors clustered at the level of the telephone access area in parentheses. ${ }^{* * *} 1 \%,{ }^{* *} 5 \%$, and ${ }^{*} 10 \%$ level of significance. Data source: GSOEP 2001 and 2008. 
Table 7: Placebo first-stage specification: OPAL access areas and Internet access in 2000

Internet access at home in 2000

Broadband Internet access (DSL) at home in 2008 (sample of individuals also observed in 2000)

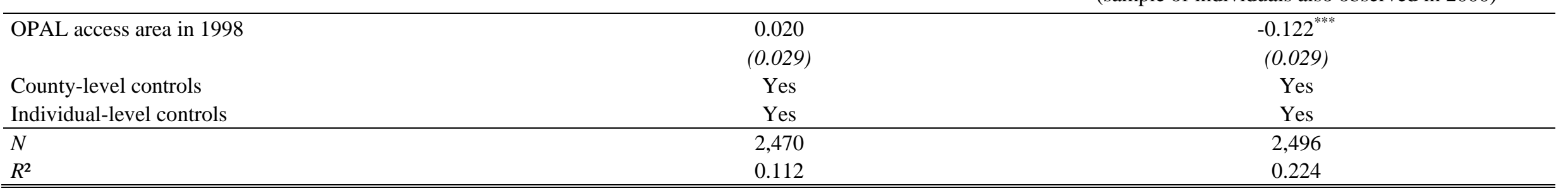

OLS regressions. Dependent variable reported on top of each column. Sample in both columns: all individuals in GSOEP 2008 living in East Germany who were also surveyed in 2000 and who did not move between telephone access areas in the meantime. Additional controls included in each model for the respective year of the dependent variable: the individual's gender, age (and its square), marital status, number of children living in the household, secondary and university education, occupational status, migration background, a dummy indicating house/flat ownership, log net household income, population density of county in 1995, GDP per capita of county in 1995, and five federal state dummies. Robust standard errors clustered at the level of the telephone access area in parentheses. ${ }^{* * *} 1 \%$, ${ }^{* *} 5 \%$, and ${ }^{*} 10 \%$ level of significance. Data source: GSOEP 2000 and 2008. 
Table 8: Broadband Internet access and social capital: Instrumental-variable results including infrastructure controls

\begin{tabular}{|c|c|c|c|c|c|c|c|c|}
\hline & \multirow{2}{*}{$\begin{array}{c}1^{\text {st }} \text { stage } \\
\text { Broadband } \\
\text { Internet access }\end{array}$} & \multicolumn{7}{|c|}{$2^{\text {nd }}$ stage } \\
\hline & & $\begin{array}{l}\text { Theater, opera, } \\
\text { and exhibitions }\end{array}$ & $\begin{array}{c}\text { Cinema } \\
\text { and concert }\end{array}$ & $\begin{array}{c}\text { Restaurant } \\
\text { and bar }\end{array}$ & $\begin{array}{l}\text { Visit } \\
\text { friends }\end{array}$ & $\begin{array}{l}\text { Volunteer } \\
\text { work }\end{array}$ & $\begin{array}{c}\text { Political } \\
\text { engagement }\end{array}$ & $\begin{array}{c}\text { Interest in } \\
\text { politics }\end{array}$ \\
\hline OPAL access area in 1998 & $\begin{array}{l}-0.115^{* * *} \\
(0.027)\end{array}$ & & & & & & & \\
\hline Broadband Internet access (DSL) at home & & $\begin{array}{l}0.684^{*} \\
(0.405)\end{array}$ & $\begin{array}{c}0.019 \\
(0.450)\end{array}$ & $\begin{array}{c}0.049 \\
(0.481)\end{array}$ & $\begin{array}{c}0.443 \\
(0.472)\end{array}$ & $\begin{array}{c}0.191 \\
(0.430)\end{array}$ & $\begin{array}{c}0.208 \\
(0.441)\end{array}$ & $\begin{array}{c}0.361 \\
(0.369)\end{array}$ \\
\hline GDP per capita 1995 & $\begin{array}{c}0.003 \\
(0.005)\end{array}$ & $\begin{array}{c}0.003 \\
(0.010)\end{array}$ & $\begin{array}{c}0.005 \\
(0.007)\end{array}$ & $\begin{array}{l}0.016^{*} \\
(0.008)\end{array}$ & $\begin{array}{c}0.012 \\
(0.007)\end{array}$ & $\begin{array}{l}-0.002 \\
(0.008)\end{array}$ & $\begin{array}{l}-0.008 \\
(0.006)\end{array}$ & $\begin{array}{l}-0.001 \\
(0.007)\end{array}$ \\
\hline Population density 1995 (/100) & $\begin{array}{c}0.003 \\
(0.004)\end{array}$ & $\begin{array}{l}0.016^{* *} \\
(0.007)\end{array}$ & $\begin{array}{l}0.011^{*} \\
((0.006)\end{array}$ & $\begin{array}{c}0.004 \\
(0.006)\end{array}$ & $\begin{array}{l}-0.004 \\
(0.006)\end{array}$ & $\begin{array}{l}-0.003 \\
(0.006)\end{array}$ & $\begin{array}{l}-0.006 \\
(0.005)\end{array}$ & $\begin{array}{c}0.002 \\
(0.006)\end{array}$ \\
\hline $\begin{array}{l}\text { Access to nearest agglomerations } \\
\text { by car or train (in } 100 \text { min.) }\end{array}$ & $\begin{array}{l}-0.005 \\
(0.067)\end{array}$ & $\begin{array}{l}-0.017 \\
(0.118)\end{array}$ & $\begin{array}{l}-0.127 \\
(0.112)\end{array}$ & $\begin{array}{c}0.017 \\
(0.113)\end{array}$ & $\begin{array}{l}-0.267^{* *} \\
(0.125)\end{array}$ & $\begin{array}{l}-0.140 \\
(0.118)\end{array}$ & $\begin{array}{c}0.043 \\
(0.126)\end{array}$ & $\begin{array}{c}0.074 \\
(0.096)\end{array}$ \\
\hline $\begin{array}{l}\text { Access to European metropolis } \\
\text { by car or airplane (in } 100 \mathrm{~min} . \text { ) }\end{array}$ & $\begin{array}{c}0.034 \\
(0.075)\end{array}$ & $\begin{array}{l}-0.193 \\
(0.136)\end{array}$ & $\begin{array}{l}-0.089 \\
(0.110)\end{array}$ & $\begin{array}{l}-0.084 \\
(0.107)\end{array}$ & $\begin{array}{l}-0.111 \\
(0.125\end{array}$ & $\begin{array}{l}-0.105 \\
(0.109)\end{array}$ & $\begin{array}{l}-0.222^{* *} \\
(0.108)\end{array}$ & $\begin{array}{c}0.014 \\
(0.108)\end{array}$ \\
\hline $\begin{array}{l}\text { Access by modern transportation } \\
\text { systems (in } 100 \text { min.) }\end{array}$ & $\begin{array}{l}-0.016 \\
(0.045)\end{array}$ & $\begin{array}{l}0.125^{*} \\
(0.071)\end{array}$ & $\begin{array}{c}0.074 \\
(0.058)\end{array}$ & $\begin{array}{c}0.096 \\
(0.063)\end{array}$ & $\begin{array}{l}0.163^{* *} \\
(0.075)\end{array}$ & $\begin{array}{c}0.099 \\
(0.069)\end{array}$ & $\begin{array}{l}-0.021 \\
(0.050)\end{array}$ & $\begin{array}{l}-0.026 \\
(0.051)\end{array}$ \\
\hline Individual-level controls & Yes & Yes & Yes & Yes & Yes & Yes & Yes & Yes \\
\hline $1^{\text {st }}$-stage $F$-statistic of excluded instrument & & 17.98 & 16.97 & 17.31 & 17.31 & 17.31 & 18.32 & 17.56 \\
\hline Robust exogeneity test: F-statistic & & 2.685 & 0.016 & 0.022 & 0.879 & 0.258 & 0.129 & 0.728 \\
\hline$p$-value & & 0.102 & 0.898 & 0.882 & 0.349 & 0.612 & 0.719 & 0.394 \\
\hline$N$ & 2,816 & 2,816 & 2,813 & 2,818 & 2,811 & 2,796 & 2,787 & 2,818 \\
\hline$R^{2}$ & 0.238 & 0.1935 & 0.389 & 0.176 & 0.123 & 0.284 & 0.211 & 0.415 \\
\hline
\end{tabular}

2SLS regressions. Dependent variable reported on top of each column. The first column reports first-stage results; the other columns report second-stage results of separate 2SLS regressions. Variables refer to 2008 unless noted otherwise. Sample: all individuals in GSOEP 2008 living in East Germany with available information on the respective social capital variable in GSOEP 2001. Additional controls included in each model: $z$-standardized lagged outcome variable measured in 2001, the individual's gender, age (and its square), marital status, number of children living in the household, secondary and university education, occupational status, migration background, a dummy indicating house/flat ownership, log net household income, and five federal state dummies. Robust standard errors clustered at the level of the telephone access area in parentheses. $^{* * *} 1 \%,{ }^{* *} 5 \%$, and ${ }^{*} 10 \%$ level of significance. Data source: GSOEP 2001 and 2008. 
Table 9: Broadband Internet access and social capital: Instrumental-variable results including county fixed effects

\begin{tabular}{|c|c|c|c|c|c|c|c|c|}
\hline & \multirow{2}{*}{$\begin{array}{c}1^{\text {st }} \text { stage } \\
\text { Broadband } \\
\text { Internet access }\end{array}$} & \multicolumn{7}{|c|}{$2^{\text {nd }}$ stage } \\
\hline & & $\begin{array}{l}\text { Theater, opera, } \\
\text { and exhibitions }\end{array}$ & $\begin{array}{c}\text { Cinema } \\
\text { and concert }\end{array}$ & $\begin{array}{c}\text { Restaurant } \\
\text { and bar }\end{array}$ & $\begin{array}{c}\text { Visit } \\
\text { friends }\end{array}$ & $\begin{array}{l}\text { Volunteer } \\
\text { work }\end{array}$ & $\begin{array}{c}\text { Political } \\
\text { engagement }\end{array}$ & $\begin{array}{c}\text { Interest in } \\
\text { politics }\end{array}$ \\
\hline OPAL access area in 1998 & $\begin{array}{c}-0.138^{* * *} \\
(0.034)\end{array}$ & & & & & & & \\
\hline Broadband Internet access (DSL) at home & & $\begin{array}{c}0.725^{*} \\
(0.377)\end{array}$ & $\begin{array}{l}-0.145 \\
(0.381)\end{array}$ & $\begin{array}{l}-0.016 \\
(0.414)\end{array}$ & $\begin{array}{l}0.948^{* *} \\
(0.477)\end{array}$ & $\begin{array}{c}0.133 \\
(0.440)\end{array}$ & $\begin{array}{l}-0.076 \\
(0.337)\end{array}$ & $\begin{array}{c}0.143 \\
(0.401)\end{array}$ \\
\hline County fixed effects (111) & Yes & Yes & Yes & Yes & Yes & Yes & Yes & Yes \\
\hline Individual-level controls & Yes & Yes & Yes & Yes & Yes & Yes & Yes & Yes \\
\hline $1^{\text {st }}$-stage $F$-statistic of excluded instrument & & 16.48 & 16.32 & 16.56 & 16.48 & 16.00 & 16.81 & 17.06 \\
\hline Robust exogeneity test: F-statistic & & 4.247 & 0.324 & 0.004 & 4.281 & 0.100 & 0.096 & 0.065 \\
\hline$p$-value & & 0.040 & 0.569 & 0.947 & 0.039 & 0.752 & 0.756 & 0.799 \\
\hline$N$ & 2,816 & 2,816 & 2,813 & 2,818 & 2,811 & 2,796 & 2,787 & 2,818 \\
\hline$R^{2}$ & 0.302 & 0.226 & 0.412 & 0.221 & 0.057 & 0.319 & 0.252 & 0.449 \\
\hline
\end{tabular}

2SLS regressions. Dependent variable reported on top of each column. The first column reports first-stage results; the other columns report second-stage results of separate 2SLS regressions. Variables refer to 2008 unless noted otherwise. Sample: all individuals in GSOEP 2008 living in East Germany with available information on the respective social capital variable also in GSOEP 2001. Additional controls included in each model: z-standardized lagged outcome variable measured in 2001, the individual's gender, age (and its square), marital status, number of children living in the household, secondary and university education, occupational status, migration background, a dummy indicating house/flat ownership, log net household income, and county dummies. Robust standard errors clustered at the level of the telephone access area in parentheses. $1 \%{ }^{* *} 5 \%$, and ${ }^{*} 10 \%$ level of significance. Data source: GSOEP 2001 and 2008. 
Table 10: Broadband Internet access and children's after-school activities

\begin{tabular}{|c|c|c|c|c|c|c|}
\hline & \multirow[t]{2}{*}{ OLS } & \multicolumn{2}{|c|}{ 2SLS } & \multirow[t]{2}{*}{ OLS } & \multicolumn{2}{|c|}{ 2SLS } \\
\hline & & $1^{\text {st }}$ stage & $2^{\text {nd }}$ stage & & $1^{\text {st }}$ stage & $2^{\text {nd }}$ stage \\
\hline & $\begin{array}{c}\text { Number of } \\
\text { out-of-school } \\
\text { social activities }\end{array}$ & $\begin{array}{l}\text { Broadband } \\
\text { Internet access }\end{array}$ & $\begin{array}{c}\text { Number of } \\
\text { out-of-school } \\
\text { social activities }\end{array}$ & $\begin{array}{c}\text { Number of } \\
\text { extra-curricular } \\
\text { activities }\end{array}$ & $\begin{array}{c}\text { Broadband } \\
\text { Internet access }\end{array}$ & $\begin{array}{c}\text { Number of } \\
\text { extra-curricular } \\
\text { activities }\end{array}$ \\
\hline OPAL access area in 1998 & & $\begin{array}{c}-0.257^{* * *} \\
(0.083)\end{array}$ & & & $\begin{array}{c}-0.257^{* * *} \\
(0.083)\end{array}$ & \\
\hline Broadband Internet access (DSL) at home & $\begin{array}{l}0.104^{* *} \\
(0.044)\end{array}$ & & $\begin{array}{l}1.037^{* *} \\
(0.413)\end{array}$ & $\begin{array}{c}0.054 \\
(0.048)\end{array}$ & & $\begin{array}{c}0.493 \\
(0.552)\end{array}$ \\
\hline Child and mother controls & Yes & Yes & Yes & Yes & Yes & Yes \\
\hline County-level controls & No & Yes & Yes & No & Yes & Yes \\
\hline $1^{\text {st }}$-stage $F$-statistic of excluded instrument & & 9.61 & & & 9.61 & \\
\hline Robust exogeneity test: $F$-statistic & & & 6.938 & & & 0.207 \\
\hline$p$-value & & & 0.009 & & & 0.650 \\
\hline$N$ & 2,453 & 338 & 338 & 2,453 & 338 & 338 \\
\hline$R^{2}$ & 0.164 & 0.214 & 43,16 & 0.038 & 0.214 & 0.100 \\
\hline
\end{tabular}

OLS and 2SLS regressions. Dependent variable reported on top of each column. Samples: OLS: all children aged 7-16 in GSOEP 2008; 2SLS: all children aged 7-16 in GSOEP 2008 living in East Germany. Additional controls included in each model: the child's gender and age, mother's marital status, number of children living in the household, mother's secondary and university education, mother's occupational status, mother's migration background, a dummy indicating house/flat ownership, log net household income, population density of county in 1995, GDP per capita of county in 1995, and five federal state dummies. The IV models additionally include population density of the county in 1995 and GDP per capita of the county in 1995 . Robust standard errors clustered at the level of the telephone access area in parentheses. ${ }^{* * *} 1 \%$, ${ }^{* *}$ $5 \%$, and ${ }^{*} 10 \%$ level of significance. Data source: GSOEP 2008. 